\title{
Descriptions of Six New Species of Jawfishes (Opistognathidae: Opistognathus) from Australia
}

\author{
WILLIAM F. SMITH-VANIZ \\ U.S. Geological Survey, Center for Aquatic Resources Studies, \\ 412 NE 16th Avenue, Gainesville, Florida 32601, United States of America \\ bill_smith-vaniz@usgs.gov
}

\begin{abstract}
Descriptions of six new species of Australian jawfishes (genus Opistognathus) are presented: O. alleni n.sp. (Western Australia), O. seminudus n.sp. (Great Barrier Reef), O. stigmosus n.sp. (Great Barrier Reef and Coral Sea Plateau), O. elizabethensis n.sp. (Tasman Sea, Elizabeth Reef), O. verecundus n.sp. (northern Australia), and O. reticeps n.sp. (northern Australia). The nominal genus Tandya Whitley is discussed and provisionally synonymized with Opistognathus Cuvier. An identification key to all Australian jawfishes is provided.
\end{abstract}

Smith-VAniz, William F., 2004. Descriptions of six new species of jawfishes (Opistognathidae: Opistognathus) from Australia. Records of the Australian Museum 56(2): 209-224.

The jawfishes, family Opistognathidae, known from tropical waters of Australian seas include two species of Stalix Jordan \& Snyder (Smith-Vaniz, 1989) and 15 species of Opistognathus Cuvier. Adults of Australian species range in size from about 30 to $409 \mathrm{~mm}$ SL (50 cm TL) and have been taken in depths of $0.3-66 \mathrm{~m}$. These diurnal fishes are obligatory burrow-dwellers and all species appear to orally incubate their eggs, which may account for the relatively high incidence of endemism (including 12 of the 17 known Australia species) in the family. Six of these endemic Australian jawfishes are new species, all of which are described below.

\section{Materials and methods}

Methods follow Smith-Vaniz (1997) and abbreviations for institutional depositories follow Leviton et al. (1985). The last two elements in the dorsal and anal fins have their bases in close approximation ("split to base" condition) and were counted as one ray in accord with the general practice of most authors, although the ultimate element has a separate rudimentary pterygiophore or stay. The short, dorsalmost element in the pectoral fin is included in the ray counts. The pattern of insertion of supraneural (= predorsal) bones and anterior dorsal-fin pterygiophores referred to as "insertion pattern" in descriptions is modified from the "predorsal formula" of Ahlstrom et al. (1976). Neural spines are indicated by slashes, a " 0 " indicates an empty interneural space; supraneurals are represented by an "S" and pterygiophores bearing a single serially associated spine are represented by a " 1 ". In material examined: cleared and stained specimens are indicated as "C\&S"; unless otherwise specified, specimen sizes are given as $\mathrm{mm}$ standard length (SL); parenthetical expressions present number of specimens, if more than one, followed by size range. 


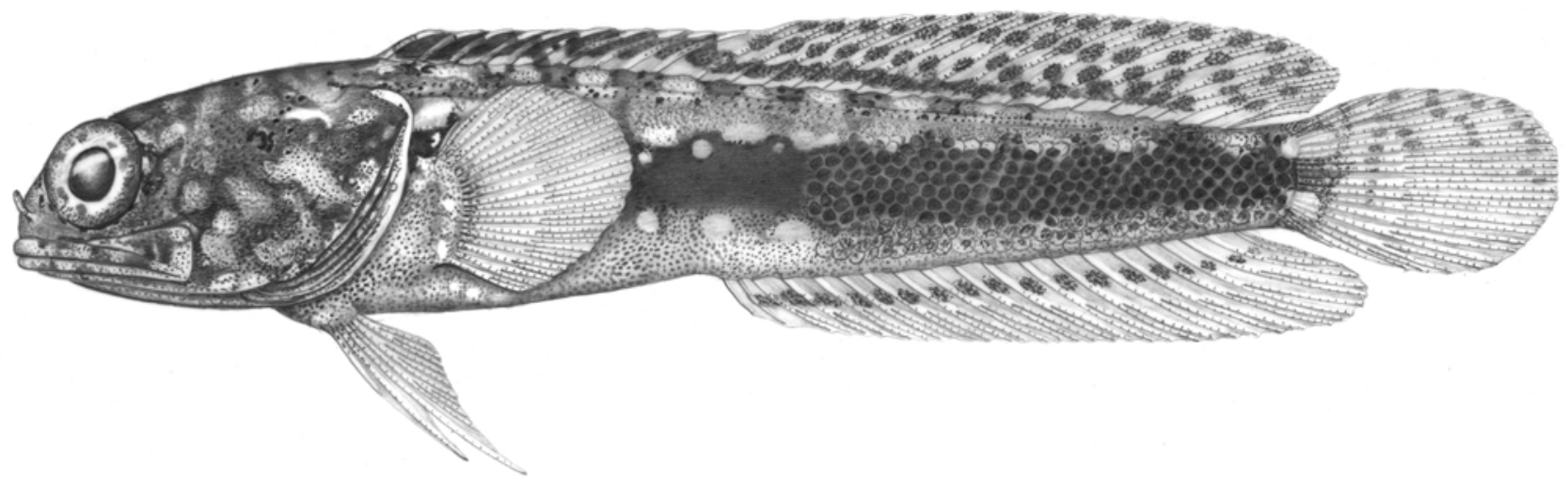

Fig. 1. Opistognathus alleni, paratype, WAM P.27590-002, female, 72.4 mm SL, Houtman Abrolhos Archipelago, Western Australia. Drawn by Jack R. Schroeder.

\section{Opistognathus alleni n.sp.}

Figs. 1, 2A, 3A, 4A; Tables 1-4

Opistognathus sp.-Allen \& Swainston, 1988:126, pl. 54, colour fig. 814 (brief diagnosis; common name "Abrolhos jawfish").

Type material. HolOTYPE: WAM P.27590-030, male (73.7), Western Australia, Houtman Abrolhos Archipelago, N. end of Dicks Island, in Goss Passage, $28^{\circ} 30^{\prime} \mathrm{S} 113^{\circ} 46^{\prime} \mathrm{E}$, 30-32 m, G.R. Allen and N. Sinclair, 17 Apr. 1982. PARATYPES: 39 specimens, 45.4-72.4 mm, all from Western Australia. WAM P.27590-002 (11, 47.4-72.4), same data as holotype; WAM P.27587-003 (54.0), Houtman Abrolhos Archipelago, S. end Long Island, in Goss Passage, $28^{\circ} 29^{\prime} \mathrm{S}$ 1134' E, 25-32 m, G.R. Allen, 16 Apr. 1982; AMS I.33668-001 (3, 51.4-66.1), ANSP 157594 (4, 53.8-66.2, 1 C\&S), NTM S.13294-001 (3, 50.5-55.1), USNM 315663 (3, 62.7-68.7) and WAM P.27595-003 (9, 45.4-51.2), Houtman Abrolhos Archipelago, all from Long Island, in Goss Passage, 30-33 m, G.R. Allen et al., 19 Apr. 1982. MPM 33192 (53.7), Exmouth Gulf, Burnside Island,

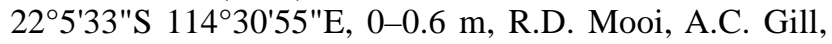
J.B. Hutchins and R.C. Miles, 19 May 1996. BMNH 2001.11.28.1 (45.3) and MPM 33191 (2, 40.6-46.8), Locker Island, $21^{\circ} 42^{\prime} 12^{\prime \prime} \mathrm{S} 114^{\circ} 45^{\prime} 48^{\prime \prime E}, 0-0.2 \mathrm{~m}$, R.D. Mooi, A.C. Gill and R.C. Miles, 16 May 1996. MPM 33190 (45.9), Bessieres Island, $21^{\circ} 31^{\prime} 2 " \mathrm{~S} 11^{\circ} 45^{\prime} 13^{\prime \prime} \mathrm{E}, 13-15 \mathrm{~m}$, R.D. Mooi, A.C. Gill, R.C. Miles and N. Williams, 15 May 1996.

Diagnosis. A species of Opistognathus with dorsal fin X, 19 (rarely 20); body with about 21-31 oblique scale rows in longitudinal series, and scales absent anterolaterally forward of verticals from 6th to 9th segmented dorsal-fin rays; spinous dorsal fin with a broad dark submarginal stripe and spine tips with pale fleshy tabs; vomerine teeth 1-3.

Description. Dorsal-fin rays X, 19 (rarely 20). Anal-fin rays II, 17-18 (typically 18). Pectoral-fin rays 19 or 20 . Caudal fin: procurrent rays $4-5+3-5$, segmented rays $8+8$, middle 12-14 branched, total elements 23-26; hypural 5 present or (usually) absent. Vertebrae: $10+22(10+23$ in one of 35 specimens); last pleural rib on vertebra 10; epineural ribs $11-15$. Supraneurals absent, insertion pattern $0 / 0 / 1 / 1+1 / 1 /$. Gill rakers 8-10+16-18 $=24-28$.

Scales absent on body anterolaterally forward of verticals from 6th to 9th segmented dorsal-fin rays, and from head, nape, area above lateral line, pectoral-fin base and breast; belly squamation varying from completely naked to posterior $1 / 4$ scaly. Body with about $21-31$ oblique scale rows in longitudinal series. Lateral-line terminus below verticals from 13th to 17 th segmented dorsal-fin rays (total element position 23-27). Lateral line pores numerous, arranged in multiple series above and below embedded lateral-line tubes. Cephalic sensory pores very numerous, in adults completely covering most of head, including all of predorsal area except a small area immediately adjacent
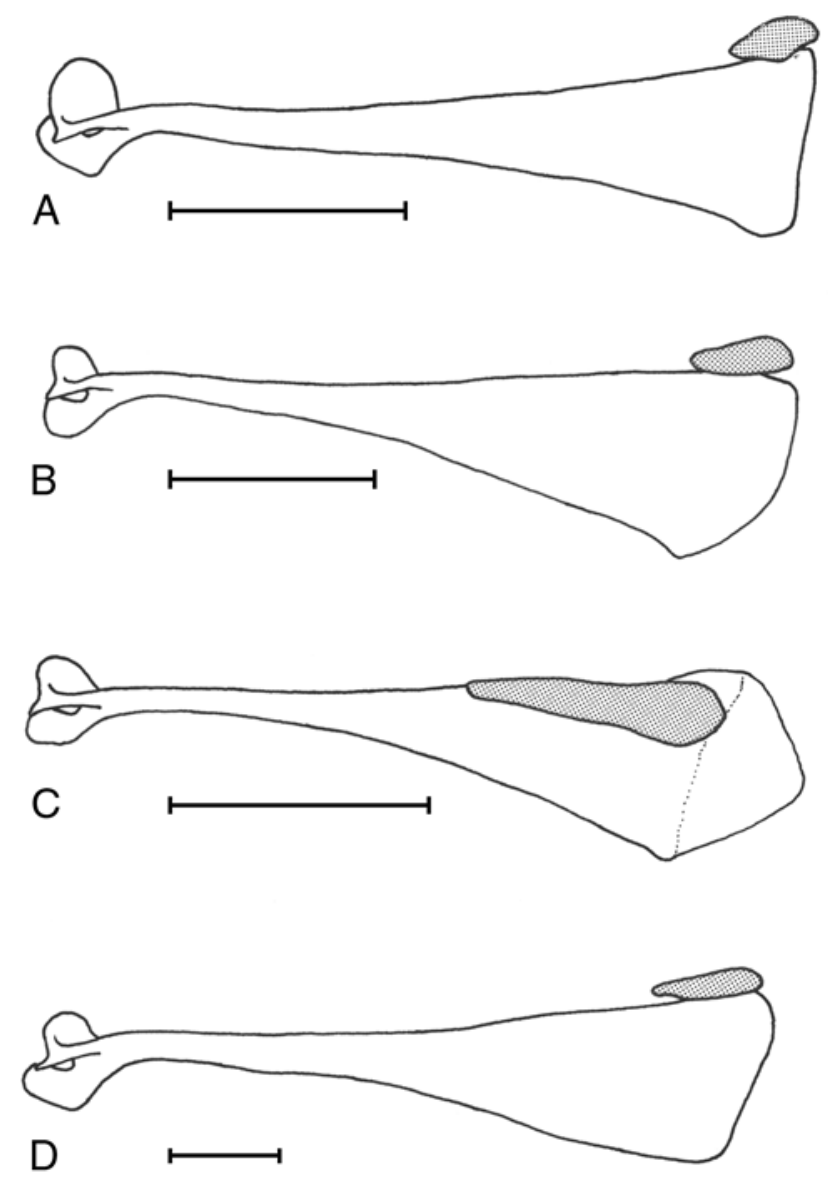

Fig. 2. Maxilla and supramaxilla (shaded): A, Opistognathus alleni; $\mathrm{B}$, O. seminudus; C, O. verecundus; D, O. reticeps. Data as in figure 3 ; scale bars represent $2 \mathrm{~mm}$. 
Table 1. Frequency distributions for certain fin-ray counts in selected Australian species of Opistognathus (holotype values in boldface).

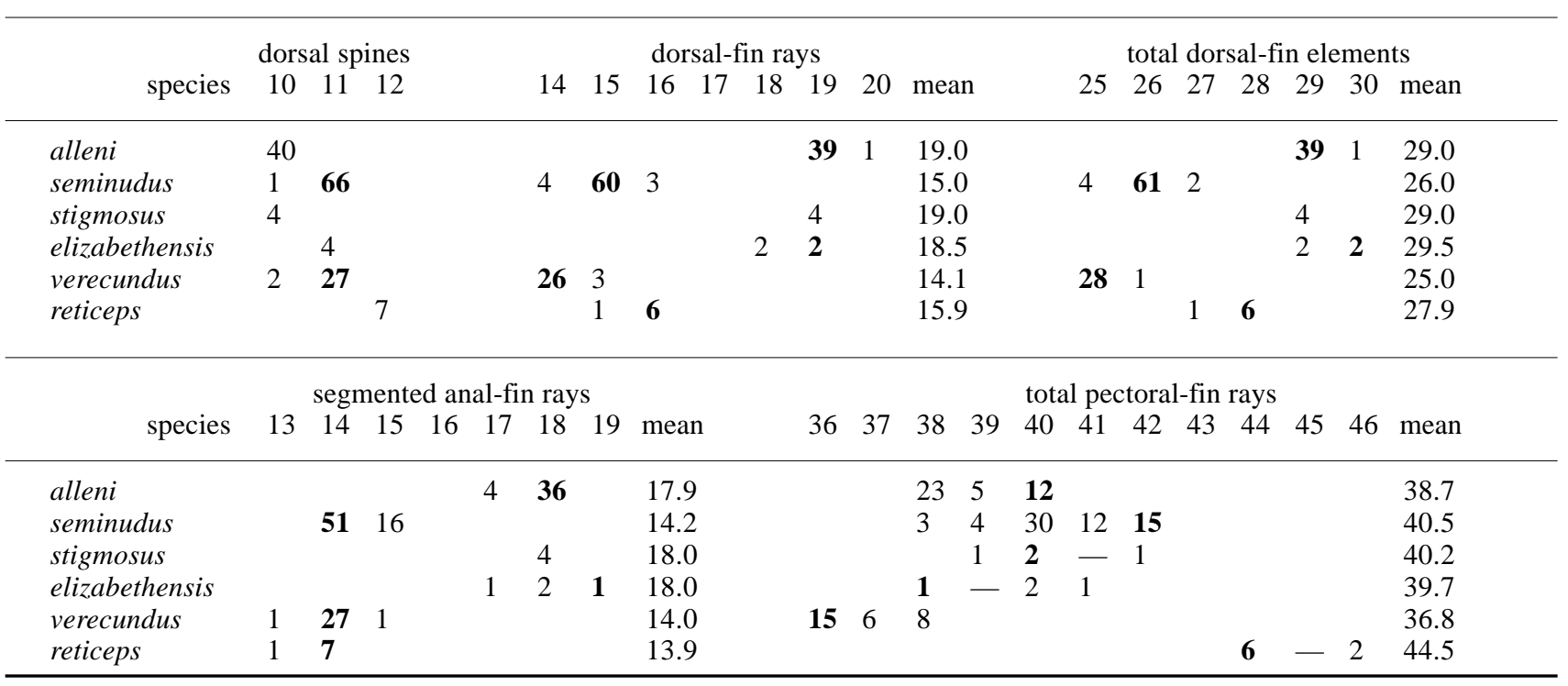

to dorsal-fin origin; mandibular pore positions 1-3 occupied by relatively large, single pores, 4th position with $6-12$ pores, 5th position with 19-30.

Anterior nostril distinctly closer to posterior nostril than to dorsal margin of upper lip, and with a simple, flattened tentacle on posterior rim that when depressed reaches margin of orbit; height of tentacle about 1.5 to 2.0 times maximum diameter of posterior nostril. Dorsal fin very low anteriorly, gradually increasing in height posteriorly; profile relatively uniform with only a slight change in fin height at junction of last spine and anterior segmented rays. Dorsalfin spines relatively short and straight, at most only slightly curved distally and without flexible tips; skin covering tips of spines with slightly swollen fleshy tabs; all segmented dorsal- and anal-fin rays branched distally. Outermost segmented pelvic-fin ray not tightly bound to adjacent ray, interradial membrane incised distally. Upper margin of opercle straight and slightly rounded posterodorsally; posterior margin of preopercle indistinct, without a free margin. No papillae on inner surface of lips. Fifth cranial nerve passes under A $1 \beta$ section of adductor mandibulae.

Upper jaw not sexually dimorphic, extending 0.4 to 0.6 eye diameters behind posterior margin of orbit; maxilla widest at end and truncate, without flexible lamina posteriorly (Fig. 2A); supramaxilla present, small and terminally positioned. Jaws subequal. Premaxilla with an outer row of moderate conical teeth that become progressively smaller and more closely spaced posteriorly and extend $2 / 3$ length of jaw; 1 or 2 rows of smaller inner teeth anteriorly, and usually 2-3 inner teeth on each side of premaxillary symphysis that are somewhat enlarged and canted backwards. Dentary with outer row of conical teeth (slightly smaller than outer symphyseal premaxillary teeth) that are usually slightly larger midlaterally, and 3 or 4 inner rows of teeth (about same size as anterior, outer row teeth) anteriorly, those in innermost row canted backwards. Vomerine teeth 1-3. Infraorbital bones tubular with wide openings for sensory canals (Fig. 3A); 3rd infraorbital relatively robust with a slight suborbital shelf. Second pharyngobranchial very slender and Y-shaped (Fig. 4A).
Measurements of the $73.7 \mathrm{~mm}$ holotype (in parentheses) and 12 paratypes, $54.3-72.4 \mathrm{~mm}$, as percentage of SL: predorsal length (31.2) 28.1-31.8; preanal length (53.4) 53.8-59.0; dorsal-fin base (71.2) 69.4-73.9; anal-fin base (40.2) 37.6-43.0; pelvic-fin length (18.0) 17.0-20.4; caudalfin length (19.5) 17.9-20.8; depth at anal-fin origin (14.2) 12.0-15.6; head length (31.3) 28.7-33.0; orbit diameter (9.2) 8.3-10.4; upper jaw length (15.0) 14.2-16.3. As percentage of head length: postorbital head length (64.9) 63.4 68.4; upper jaw length (47.9) 46.8-52.0; postorbital jaw length (16.3) 13.5-17.4; orbit diameter (29.3) 29.0-32.8.

Preserved coloration. Head and body with scattered pale spots and mottled with various shades of brown; sides with dark midlateral stripe about width of eye and bordered above and below by a row of pale spots, some poorly defined, that contact margins of stripe giving it a scalloped outline; dorsum of some specimens with about 8-10 evenly spaced tan blotches superimposed with small dark spots that extend slightly below lateral line along dorsal-fin base and alternate with upper row of pale spots; pectoral-fin base with large white spot (not shown in illustrated specimen); posterodorsal margin of opercular flap with dark margin; in large specimens, dusky spots usually ring orbital rim, at least dorsally; upper lip with 1 or 2 dusky bands below or slightly behind posterior margin of eye; inner lining of maxilla and mouth pale or light brown but without a distinct blotch or stripe; spinous dorsal fin with a broad submarginal brown stripe and spine tips with noticeably pale fleshy tabs; soft dorsal fin with a narrow dark stripe near base of fin that is bordered above by several rows of small dark spots or blotches; anal fin mostly pale, usually with very narrow brown stripe on proximal third of fin; caudal fin with a pair of pale, oblong, basicaudal spots widely separated by a brown blotch that is a continuation of the midlateral stripe; otherwise caudal fin mostly pale with very faint dusky bands or spots that are best developed on dorsal half of fin; pelvic and pectoral fins immaculate. Some of the non-Houtman Abrolhos Archipelago paratypes (which appear to have better preserved colour patterns) have 

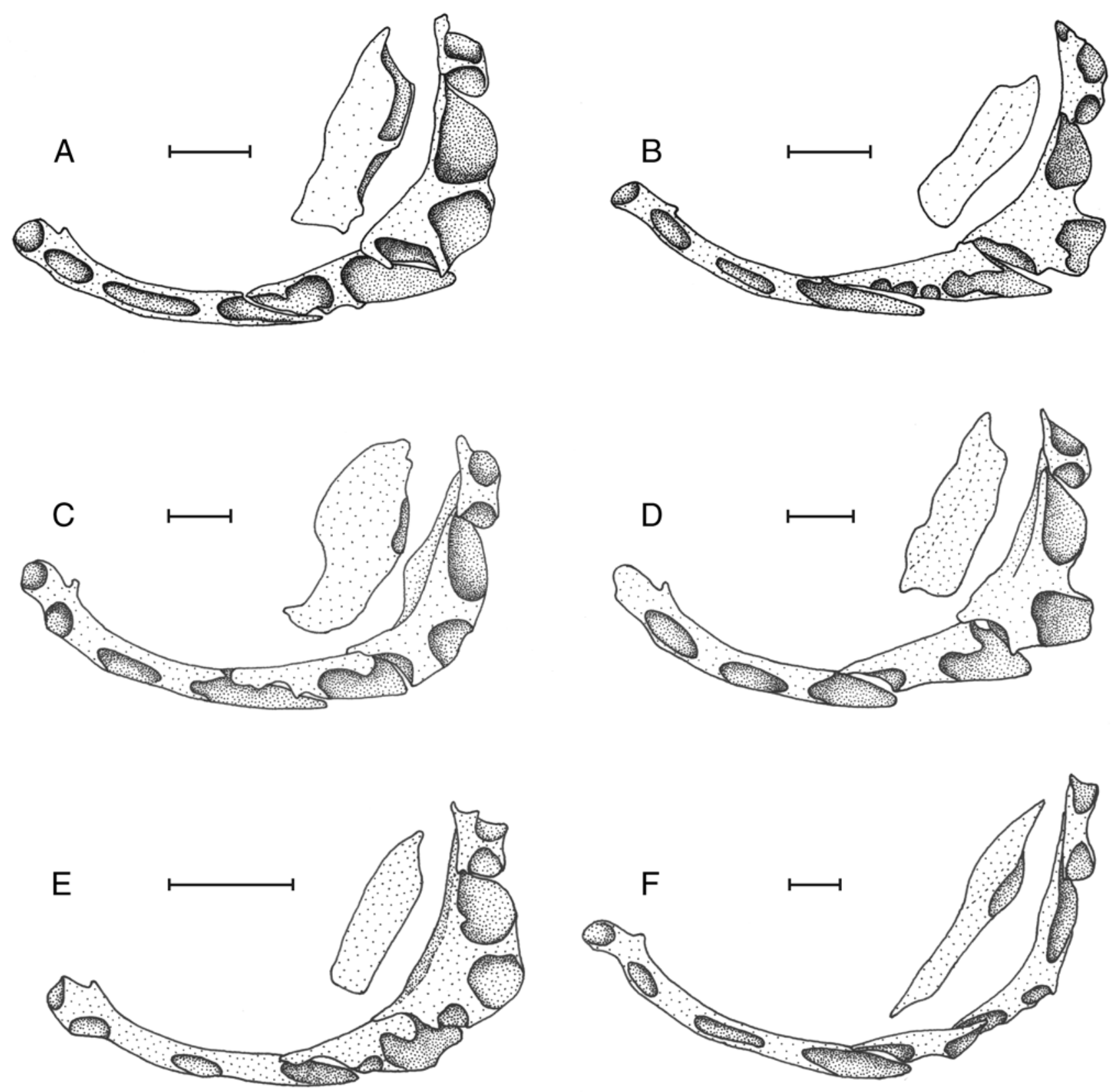

Fig. 3. Lateral views of left infraorbital bones (3rd infraorbital also in rotated dorsal view), excluding dermosphenotic: A, Opistognathus alleni, ANSP 157594, $54.3 \mathrm{~mm} \mathrm{SL}$; B, O. seminudus, ANSP 142950, $55.0 \mathrm{~mm}$ SL; C, O. stigmosus, WAM P.29641-001, 62.5 mm SL; D, O. elizabethensis, AMS I.27891-048, 66.6 mm SL; E, O. verecundus, ANSP 167416, 36.9 mm SL; F, O. reticeps, NTM S.10718032, $63.7 \mathrm{~mm}$ SL. Scale bars represent $1 \mathrm{~mm}$.

a conspicuous white cheek spot, positioned slightly below the mid-point of postorbital margin of eye that is bordered above by a small dark spot, and 1 or 2 white spots on the opercule.

Live coloration (based on photograph, taken by R.D. Mooi, of freshly collected $53.7 \mathrm{~mm}$ SL specimen from Burnside Is.): dark chocolate brown stripe in dorsal and anal fins and midlaterally on sides; background coloration of head and body light yellowish brown; pale spots on cheek, opercle, pectoralfin base and most of those below midlateral stripe on sides white, other pale spots light yellowish brown; iris pale yellow with a few narrow dark bands radiating from pupil. This individual also has small prominent white spots on the belly that are either absent or less defined in the other specimens.
Etymology. Named in honour of Dr Gerald R. Allen, who recognized the undescribed status of this species, generously made his material available for this study, and whose publications have contributed significantly to knowledge of Indo-Pacific fishes.

Distribution. Known only from Western Australia in depths of $0.2-33 \mathrm{~m}$.

Remarks. In O. alleni the second pharyngobranchial is very slender and essentially Y-shaped (Fig. 4A), in most other species of Opistognathus this edentate bone is rod-like with the distal end slightly to moderately expanded (character not examined in $O$. stigmosus and $O$. elizabethensis), and in O. seminudus the end is greatly expanded (Fig. 4B). 


\section{Opistognathus seminudus n.sp.}

Figs. 2B, 3B, 4B, 5, 6; Tables 1-4

Opistognathus sp.-Russell, 1983:107 (listed; Heron and One Tree islands).

Type material. Holotype: AMS I.22794-001, female (59.7), Australia, Great Barrier Reef, Capricorn Group, One Tree Island, reef flat at SW end of island, 0-1 m, V.G. Springer, 30 Nov. 1966, Sta. 66-13. PARATYPES: 78 specimens, 17.7-86.2 mm, all from the Great Barrier Reef. Capricorn Group, One Tree Island: ANSP 142950 (8, 21.573.7, 3 C\&S) and USNM $220928(14,59.5-3.7)$, same data as holotype; AMS I.15641-042 (73.2), AMS I.15681-063 (4, 60.7-76.1), AMS I.17445-031 (9, 73.0-47.3), 3 m, F. Talbot, 19 Sep. 1968; AMS I.20201-028 (60.0), 0-2 m, D. Hoese, 29 Sep. 1971; AMS I.20212-004 (2, 50.9-85.5), 20 m, F. Talbot et al., 6 Oct. 1971; BPBM 14385 (3, 33.070.5), 0.5-1.5 m, J.E. Randall, Jan. 1973; CAS 13790 (1, 72.4), 0.5 m, B.B. Collette and W.N. Eschmeyer, 22 Nov. 1969; CAS 13818 (3, 17.7-63.9), 6 m, F. Talbot et al., 26 Nov. 1969; USNM 220941 (26.6), 8-12 m, V.G. Springer, 7 Dec. 1966; USNM 220942 (67.8), 4 m, V.G. Springer, 1 Dec. 1966; USNM 220943 (9, 23.3-74.6), 5 m, V.G. Springer, 25 Nov. 1966; USNM 220944 (6, 61.0-77.4), 1 m, V.G. Springer, 27 Nov. 1966; and USNM 295803 (3, 80.3-86.2), 4.5 m, V.G. Springer, 11 Dec 1966. Capricorn Group, Wistari Reef: BPBM 14535 (54.0), 22 m, J.E. Randall, 22 Jan. 1973. Capricorn Group, Heron Island: AMS IB.4054-5 (2, 59.8-64.9), AMS I.15482-002 (48.6), H. Choat, 16 Jun. 1965; and USNM 295804 (64.9), H. Choat, 23 Feb. 1967. Gillett Cay: AMS IB.6126 (76.0), AMS IB.6127 (71.9), and AMS IB.6128 (3, 49.8-54.7), Swains Reef Expedition, Oct. 1962. Lizard Island: AMS I.20766010 (2, 54.5-57.7), D. Hoese et al., 6 Feb. 1975.

Diagnosis. A species of Opistognathus with dorsal fin XI (exceptionally X), 14-16; body with about 28-36 oblique scale rows in longitudinal series, and with scales absent anterolaterally forward of verticals from ultimate spine to 2nd segmented dorsal-fin ray; dorsal fin with conspicuous ocellus between spines 2-5; vomerine teeth 1-3.

Description. Dorsal-fin rays XI (exceptionally X), 14-16. Anal-fin rays II, 14-15. Pectoral-fin rays 19-21. Caudal fin: procurrent rays 4-6+4-5, segmented rays $8+8$, middle 12-14 branched, total elements 24-27; hypural 5 present. Vertebrae: $10+18(10+19$ in one of 68 specimens); last pleural rib on vertebra 10; epineural ribs $12-15$. Supraneurals absent, insertion pattern $0 / 0 / 1 / 1+1 / 1 /$. Gill rakers $8-10+16-18=24-27$.

Scales absent on body anterolaterally forward of verticals from ultimate spine to 2 nd segmented dorsal-fin ray, and from head, above lateral line, pectoral-fin base, breast and belly. Body with about 28-36 oblique scale rows in longitudinal series. Lateral-line terminus below verticals from 7 th to 11 th segmented dorsal-fin rays (total element position 18-22). Lateral line pores numerous, arranged in multiple series along embedded lateral-line tubes. Cephalic sensory pores very numerous (Fig. 6), in adults completely covering most of head, including all of predorsal area except a small area immediately adjacent to dorsal-fin origin; mandibular pore positions 1-3 occupied by relatively large, single pores, 4 th position with $4-10$ pores, 5 th position with $12-24$.
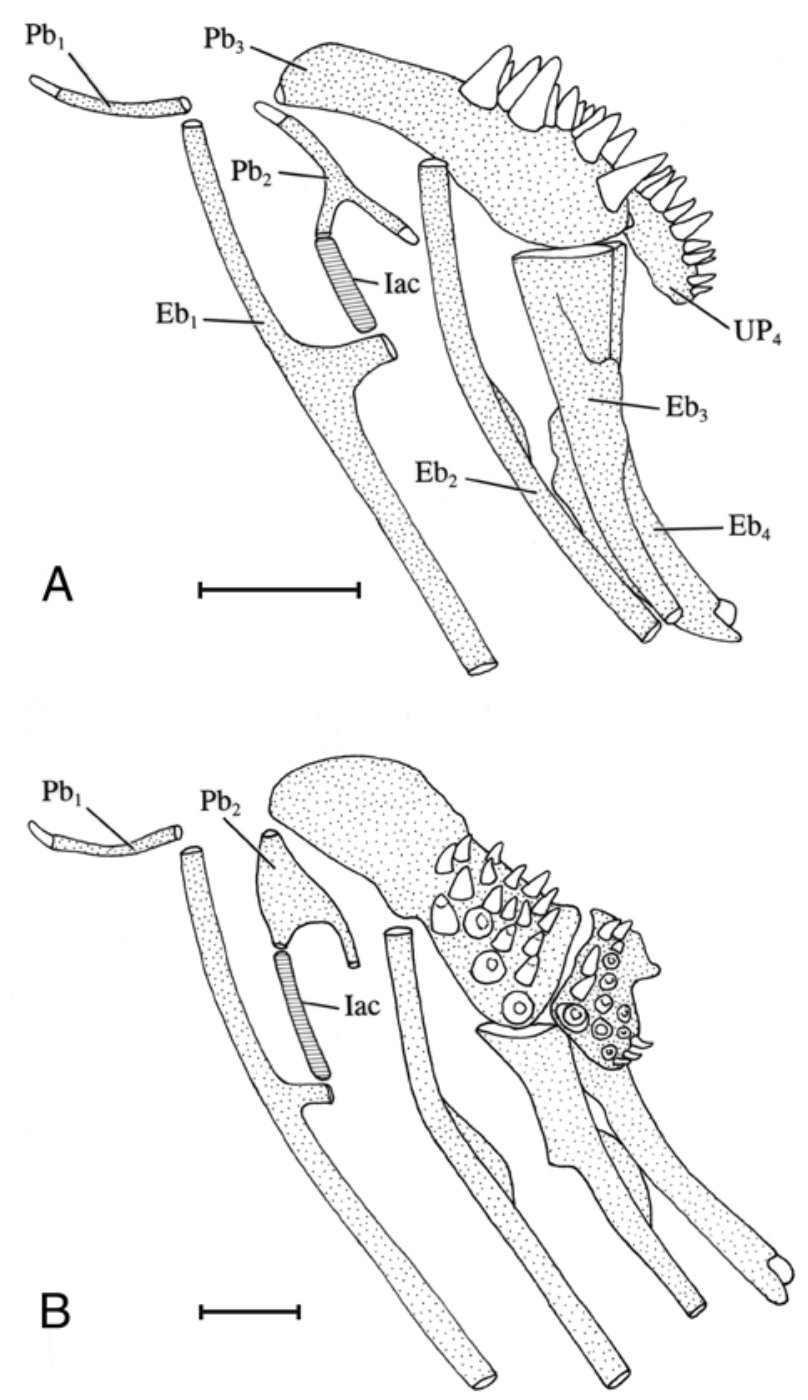

Fig. 4. Dorsal gill arches (right side, ventral views): A, Opistognathus alleni, ANSP 157594, $54.3 \mathrm{~mm} \mathrm{SL}$; B, O. seminudus, ANSP 142950, $55.0 \mathrm{~mm} \mathrm{SL}$. Eb = epibranchial, $\mathrm{Pb}=$ pharyngobranchial, Iac = interarcual cartilage, UP upper pharyngeal toothplate; scale bars represent $1 \mathrm{~mm}$.

Anterior nostril distinctly closer to posterior nostril than to dorsal margin of upper lip, and with a simple, flattened tentacle on posterior rim that when depressed usually reaches margin of orbit; height of tentacle about 1.5 to 2.0 times maximum diameter of posterior nostril. Dorsal fin very low anteriorly, gradually increasing in height posteriorly; profile relatively uniform with only a slight change in fin height at junction of last spine and anterior segmented rays. Dorsal-fin spines relatively short and straight, at most only slightly curved distally and without flexible tips; tips of spines with slightly swollen fleshy tabs; all segmented dorsal- and anal-fin rays branched distally or 1 st anal ray unbranched. Outermost segmented pelvic-fin ray not tightly bound to adjacent ray, interradial membrane incised distally. Upper margin of opercle straight and slightly rounded posterodorsally; posterior margin of preopercle indistinct without a free margin. No papillae on inner surface of lips. Fifth cranial nerve passes under $A 1 \beta$ section of adductor mandibulae. 


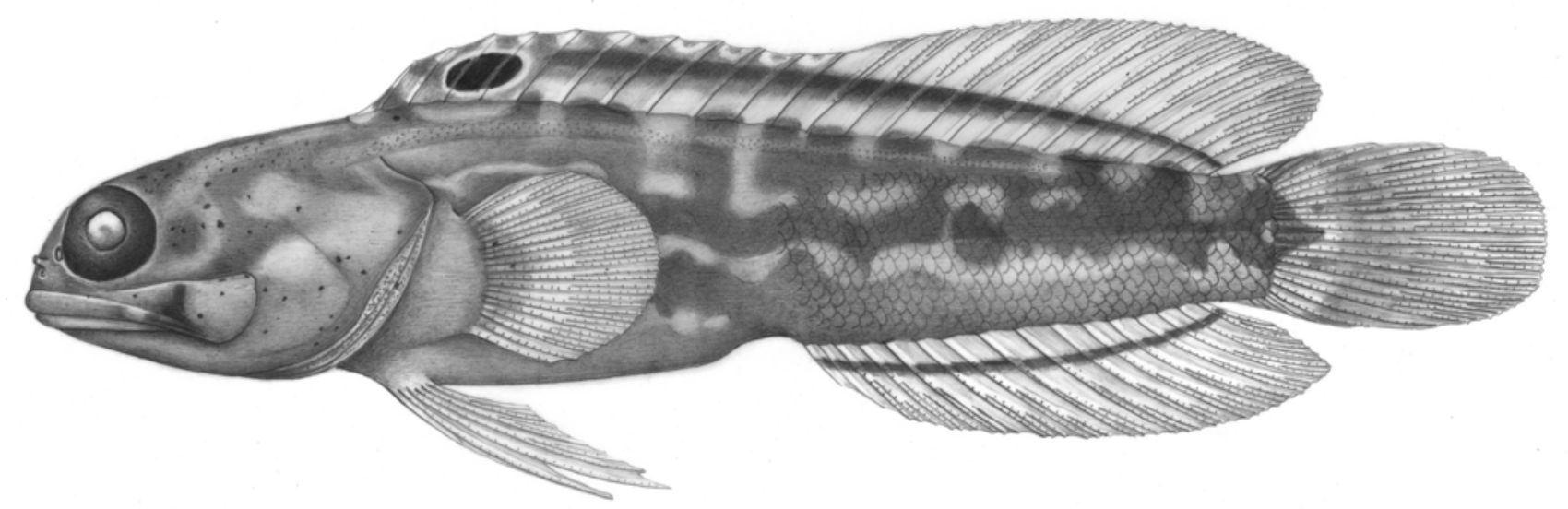

Fig. 5. Opistognathus seminudus, paratype, AMS I.15681-063, male, $76.1 \mathrm{~mm}$ SL, One Tree Island, Great Barrier Reef. Drawn by Jack R. Schroeder.

Upper jaw slightly sexually dimorphic, extending 0.8 to $1.1(\widehat{\partial} \widehat{\delta})$ and $0.6-0.9$ ( $(+q)$ eye diameters behind posterior margin of orbit; maxilla widest at end and rounded, without flexible lamina posteriorly (Fig. 2B); supramaxilla present, small and terminally positioned. Jaws subequal. Premaxilla with an outer row of stout conical teeth that become progressively smaller posteriorly; 1 or 2 inner rows of smaller conical teeth anteriorly, those nearest symphysis largest and usually canted backward. Dentary with an outer row of moderate teeth, largest midlaterally, extending $1 / 2$ to $2 / 3$ length of jaw, and an inner row of smaller conical teeth anteriorly that are usually strongly hooked backward. Vomerine teeth 1-3. Infraorbital bones tubular, with wide openings for sensory canals (Fig. 3B); 3rd infraorbital relatively robust and "L" shaped with a slight suborbital shelf. Second pharyngobranchial rod-shaped with distal end greatly expanded (Fig. 4B).

Measurements of the $59.7 \mathrm{~mm}$ female holotype (in parentheses) and 23 paratypes, 13 ot 0 57.9-86.2 $\mathrm{mm}$ and 10 o + 60.6-73.7 mm, as percentage of SL: predorsal length (30.9) 29.9-35.0; preanal length (58.6) 58.8-64.7; dorsalfin base (67.0) 62.9-70.1; anal-fin base (31.6) 29.4-35.4; pelvic-fin length (24.6) 17.3-25.2; caudal-fin length (22.3) 21.4-24.8; depth at anal-fin origin (16.9) 14.9-19.1; head length (34.0) 33.0-36.2; orbit diameter (11.5) 9.9-11.5; upper jaw length (19.4) 19.9-22.3 ô के, 18.8-22.1. As percentage of head length: postorbital head length (63.6) 62.6-69.0; upper jaw length (57.1) 56.8-64.0 ôे ô, 55.1-

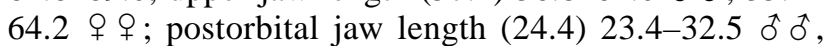
19.5-25.7 9 \% ; orbit diameter (34.0) 27.5-33.6.

Preserved coloration. Head and body various shades of brown; several irregular, wavy rows of pale marking or oblong spots on body and a wedge-shaped basicaudal blotch extending onto middle caudal-fin rays; larger specimens with many tiny black spots scattered on head and jaws; branchiostegal membranes and inner lining of maxilla and adjacent membranes dark brown, and a dark diagonal blotch externally on upper jaw positioned at rictus of mouth; dorsal fin mostly pale except conspicuous ocellus between spines $2-5$ and a narrow dark stripe immediately behind ocellus (only a continuous dark stripe in small juveniles) extending length of fin diagonally to just above base of last ray; dorsalfin spines with distinctly pale slightly fleshy tabs; anal fin pale with a narrow, suprabasal, dark stripe; pelvic, pectoral, and caudal fins immaculate.
Live coloration (based on aquarium photograph taken by P.C. Heemstra, of a $79.4 \mathrm{~mm}$ SL specimen from Heron Is.): pale background coloration of head and body mostly white, as are pale areas in fins; spot in ocellus black and other dark areas various shades of brown.

Etymology. The specific epithet, from the Latin semi (half) and nudus (bare, naked), refers to the naked anterior half of the body.

Distribution. Endemic to the Great Barrier Reef where collected in $0.5-22 \mathrm{~m}$.

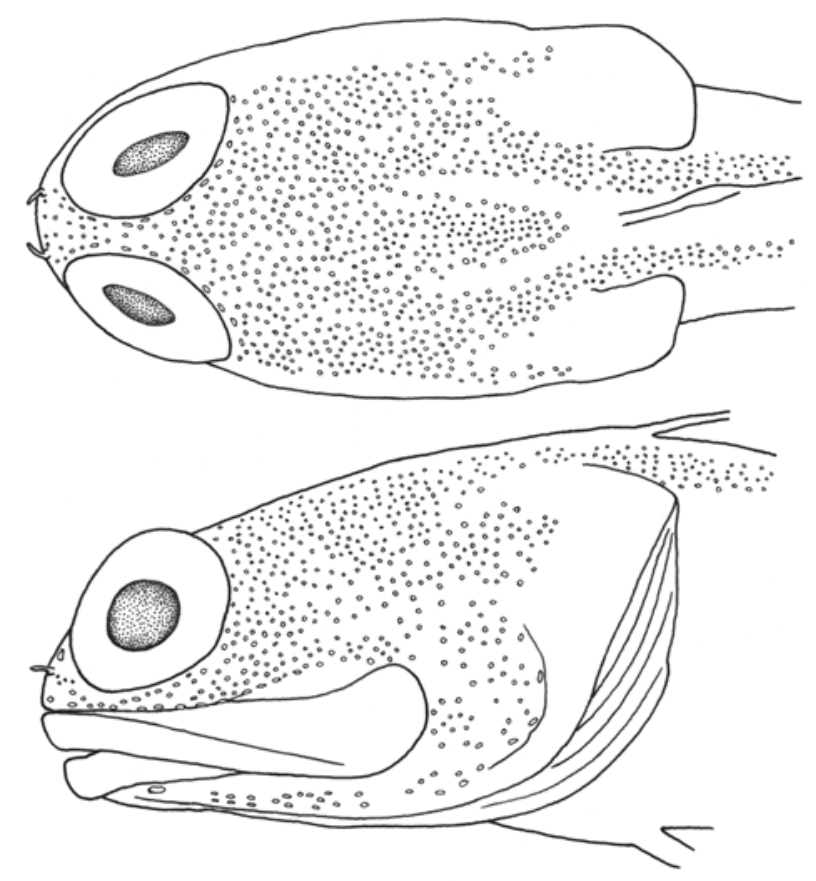

Fig. 6. Cephalic sensory pores of Opistognathus seminudus, AMS I.17445-031, male, 64.0 mm SL, One Tree Island, Great Barrier Reef. 


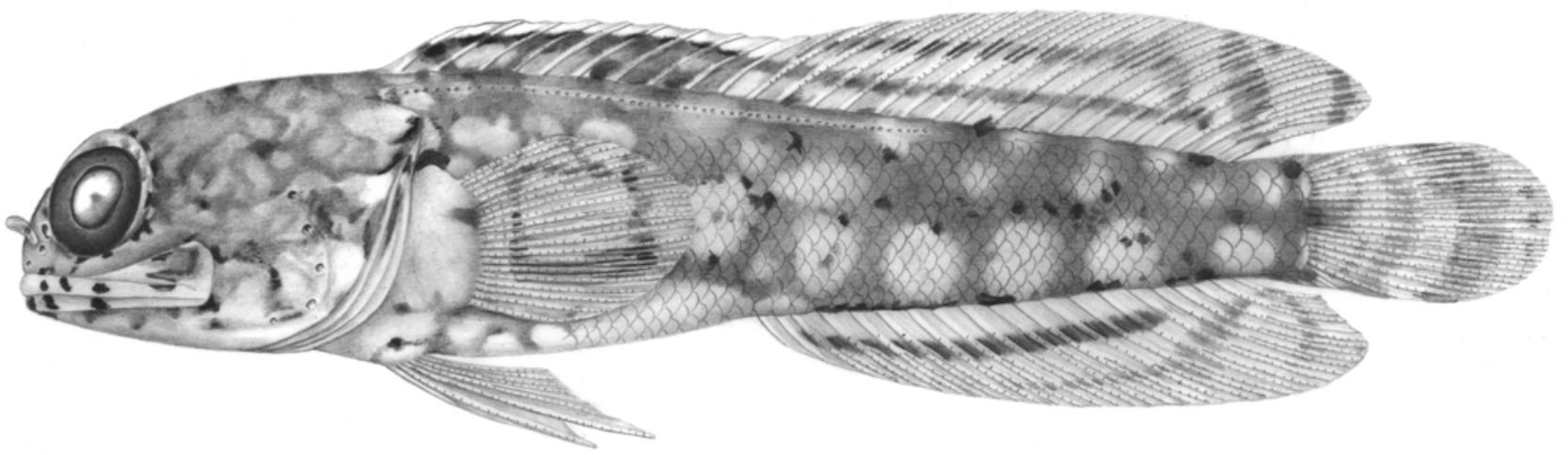

Fig. 7. Opistognathus stigmosus, holotype, AMS I.22583-004, male, 70.6 mm SL, Escape Reef, Queensland, Australia. Drawn by Jack R. Schroeder.

\section{Opistognathus stigmosus n.sp.}

Figs. 3C, 7; Tables 1-4

Opistognathus sp.-Randall et al., 1990: 356, unnumbered colour fig. (brief diagnosis; common name "coral sea jawfish").

Type material. HOLOTYPE: AMS I.22583-004, male (70.5), Australia, Queensland, Escape Reef, $15^{\circ} 49^{\prime} \mathrm{S} 145^{\circ} 50^{\prime} \mathrm{E}$, outer reef, 29 m, G.R. Allen, T. Ayling and W. Starck, 29 Oct. 1981, sta. ER $81-11$. PARATYPES: 3 specimens, $42.9-62.5 \mathrm{~mm}$, all from the Great Barrier Reef. AMS I.22583-037, sex undetermined (42.9), same data as holotype; WAM P.27467004, gravid female (58.5), Escape Reef, G.R. Allen et al., 30 Oct 1981; WAM P.29641-001, male (62.5), Lihou Reef, Juliette Cay, 17²1'S 151³3'E, 20-23 m, G.R. Allen, 14 Nov. 1987.

Diagnosis. A species of Opistognathus with dorsal fin X, 19; body with about 38-45 oblique scale rows in longitudinal series, and with scales absent anterolaterally forward of verticals from 5 th to 7 th dorsal-fin spines; lower half of sides with longitudinal row of 7 or 8 large white spots, the largest with a dark brown border and covered by appressed pectoral fin; vomerine teeth absent.

Description. Dorsal-fin rays X, 19. Anal-fin rays II, 18. Pectoral-fin rays 19-21. Caudal fin: procurrent rays 5+45 , segmented rays $8+8$, middle 14 branched, total elements 25-26; hypural 5 absent. Vertebrae: 10+23; last pleural rib on vertebra 10; epineural ribs 13-14. Supraneurals absent, insertion pattern 0/0/1/1+1/1/. Gill rakers $7-9+15-18=22-27$.

Scales absent on body anterolaterally forward of verticals from 5th to 7th dorsal-fin spines, and from head, nape, above lateral line, pectoral-fin base, breast and anterior $1 / 3$ of belly. Body with about $38-45$ oblique scale rows in longitudinal series. Lateral-line terminus below verticals from 7th or 8th segmented dorsal-fin rays (total element position 17 or 18). Lateral line pores numerous, arranged in multiple series above and below embedded lateral-line tubes. Cephalic sensory pores very numerous, in adults completely covering most of head, including all of predorsal area except a small area immediately adjacent to dorsal-fin origin; mandibular pore positions 1-3 occupied by relatively large, single pores, 4 th position with $2-$ 5 pores, 5 th position with $6-12$.

Anterior nostril distinctly closer to posterior nostril than to dorsal margin of upper lip, and with a simple, relatively long tentacle on posterior rim that when depressed usually barely reaches to or almost to margin of orbit; height of tentacle about 1.5 times maximum diameter of posterior nostril. Dorsal fin low anteriorly gradually increasing in height posteriorly; profile relatively uniform with only a slight change in fin height at junction of spinous and segmented rays. Dorsal-fin spines relatively short and straight, at most only slightly curved distally and without flexible tips; skin covering tips of spines with slightly swollen fleshy tabs; all segmented dorsal- and anal-fin rays branched distally. Outermost segmented pelvic-fin ray not tightly bound to adjacent ray, interradial membrane incised distally. Upper margin of opercle straight and slightly rounded posterodorsally; posterior margin of preopercle indistinct without a free margin. No papillae on inner surface of lips. Fifth cranial nerve passes under A $1 \beta$ branch of adductor mandibulae.

Upper jaw not sexually dimorphic, extending 0.4 to 0.5 eye diameters behind posterior margin of orbit; maxilla widest at end and truncate, without flexible lamina posteriorly; supramaxilla present, small and terminally positioned. Jaws subequal. Premaxilla with moderate conical teeth in outer row that become progressively smaller and more closely spaced posteriorly; 1-3 irregular rows of smaller, sharply pointed, inner teeth anteriorly, those in innermost row slightly larger and canted backwards. Dentary with outer row of conical teeth, all about the same size and about $1 / 2$ size of largest premaxillary teeth; $1-4$ irregular, inner rows of slightly smaller conical teeth anteriorly, those in innermost row slightly canted backwards. Vomerine teeth absent. Infraorbital bones tubular, with wide openings for sensory canals (Fig. 3C), third infraorbital relatively robust with a slight suborbital shelf.

Measurements of the $70.5 \mathrm{~mm}$ holotype (in parentheses) and 3 paratypes, $42.9-62.5 \mathrm{~mm}$, as percentage of SL: predorsal length (35.2) 32.8-35.0; preanal length (54.9) 55.6-58.6; dorsal-fin base (69.1) 67.4-71.8; anal-fin base (34.5) 36.3-36.7; pelvic-fin length (23.0) 23.0-23.6; caudalfin length (19.4) 19.4-22.3; depth at anal-fin origin (15.6) 13.9-16.3; head length (34.5) 33.5-35.0; orbit diameter (11.5) 11.5-12.1; upper jaw length (19.3) 17.3-19.0. As percentage of head length: postorbital head length (61.2) 59.3-61.7; upper jaw length (55.9) 51.5-54.3; postorbital jaw length (15.2) 12.814.0; orbit diameter (33.3) 34.2-34.7. 
Table 2. Frequency distributions of gill-raker counts in selected Australia species of Opistognathus (values for holotypes in boldface).

\begin{tabular}{|c|c|c|c|c|c|c|c|c|c|c|c|c|c|c|c|c|c|c|c|c|}
\hline \multirow[b]{2}{*}{ species } & \multicolumn{5}{|c|}{ upper gill-rakers } & \multicolumn{6}{|c|}{ lower gill-rakers } & \multicolumn{9}{|c|}{ total gill-rakers } \\
\hline & 7 & 8 & 9 & 10 & mean & 15 & 16 & 17 & 18 & 19 & mean & 22 & 23 & 24 & 25 & 26 & 27 & 28 & 29 & mean \\
\hline alleni & & 13 & 26 & 1 & 8.7 & & 11 & 27 & 2 & & 16.8 & & & 6 & 12 & 20 & 1 & 1 & & 25.5 \\
\hline seminudus & & 32 & 30 & 1 & 8.5 & & 14 & 41 & 8 & & 16.9 & & & 8 & 28 & 19 & 8 & & & 25.4 \\
\hline stigmosus & 1 & 2 & 1 & & 8.0 & 1 & 1 & 1 & 1 & & 16.5 & 1 & - & 1 & 1 & - & 1 & & & 24.5 \\
\hline elizabethensis & & 4 & & & 8.0 & & 1 & 3 & & & 16.7 & & & 1 & 3 & & & & & 24.8 \\
\hline verecundus & & 11 & 13 & & 8.5 & 10 & 13 & 1 & & & 15.6 & & 5 & 11 & 7 & 1 & & & & 24.2 \\
\hline reticeps & & & 6 & 1 & 9.1 & & & 1 & 5 & 1 & 18.0 & & & & & 1 & 5 & - & 1 & 27.2 \\
\hline
\end{tabular}

Preserved coloration. Head and body overall tan, longitudinal row of 7 or 8 large white spots on lower half of sides; the largest with a dark brown border, widest ventrally, and covered by appressed pectoral fin; a second row of smaller indistinct pale spots above primary row; laterally a small dark spot present opposite dorsal $1 / 3$ of otherwise pale pectoral-fin base; this spot on mesial side of pectoral-fin base where it may continue downward as a diagonal mark; small dark blotch also present on body immediately above pectoral-fin base; head and sides punctuated with widely scattered small dark brown spots, including one just behind posterodorsal margin of upper jaw; other dark spots ring orbital rim, those in interorbital region always very dark and symmetrically arranged in bilateral pairs; conspicuous dark spots or bands on upper and lower lips, two largest specimens each with 6 bands on lower lip; inner lining of maxilla and mouth immaculate; spinous dorsal fin with submarginal narrow dark stripe; tips of dorsal-fin spines with noticeably pale fleshy tabs; soft dorsal and anal fins with narrow dark suprabasal stripe bordered above by diffuse submarginal brown stripe, and dark bands or spots; caudal fin with pair of pale basicaudal spots (separated by a narrow inverted wedge-shaped blotch with a pale centre) followed by 1 or 2 dusky bands separated by pale interspaces; pelvic and pectoral fins immaculate.

Live coloration (based on Randall et al., 1990): body and head various shades of brown, pale spots and markings white; iris yellow with a few narrow dark bands radiating from pupil.

Etymology. The specific epithet, from the Latin stigmosus (full of marks), refers to the conspicuous, small dark spots on the head of this species.

Distribution. Known only from the Great Barrier Reef (Escape Reef) and the Coral Sea Plateau (Lihou Reef) in 20-29 m.

\section{Opistognathus elizabethensis n.sp.}

Figs. 3D, 8; Tables 1-4

“Opistognathus n.sp.”.-Gill \& Reader. 1992:220 (listed in annotated checklist of fishes collected at Middleton and Elizabeth Reefs).

Type material. HOLOTYPE: AMS I.27891-010, male (60.4), Elizabeth Reef, $\mathrm{N}$ side near lagoon entrance, $29^{\circ} 56^{\prime} \mathrm{S}$ $159^{\circ} 01^{\prime} \mathrm{E}, 0-5 \mathrm{~m}$, explosives, D.M. Williams, et al., Dec. 1981. PARATYPES: 3 specimens, 66.6-71.4 mm. AMS I.27891-048, gravid females $(2,66.6-70.8)$, same data as holotype; AMS I.27152-014, male (71.4), Elizabeth Reef, outer SW reef slope, $29^{\circ} 57^{\prime} \mathrm{S} 159^{\circ} 02^{\prime} \mathrm{E}, 15-18 \mathrm{~m}$, A. Gill and S. Reader, 10 Dec. 1987.

Diagnosis. A species of Opistognathus with dorsal fin XI, 18 or 19 ; body with about $47-51$ oblique scale rows in longitudinal series, and scales absent anterolaterally forward of verticals from 6th or 7th dorsal-fin spine; dorsal fin with an oblong black spot (partially encircled by white border) between spines 3-6 that extends slightly onto dorsum; vomerine teeth 2 or 3 .

Description. Dorsal-fin rays XI, 18-19. Anal-fin rays II, 17-19. Pectoral-fin rays 19-21. Caudal fin: procurrent rays 5-6+4-5, segmented rays $8+8$, middle 13 or 14 branched, total elements 25 or 27 ; hypural 5 absent. Vertebrae: $10+23$; last pleural rib on vertebra 10; epineural ribs 13-14. Supraneurals absent, insertion pattern $0 / 0 / 1 / 1+1 / 1 /$. Gill rakers $8+16-17=24-25$.

Scales absent on body anterolaterally forward of verticals from 6th or 7th dorsal-fin spines, and from head, nape, above and slightly below lateral line, pectoral-fin base, breast and anterior $1 / 3$ of belly. Body with about $47-51$ oblique scale rows in longitudinal series. Lateral-line terminus below verticals from 4 th to 7 th segmented dorsal-fin ray (total

Table 3. Frequency distributions of oblique scale rows in longitudinal series in selected Australian species of Opistognathus (values for holotypes in boldface). Asterisk following species name indicates that bilateral counts were made.

oblique scale rows

$\begin{array}{lllllllllllllllllllllllll}21 & 23 & 25 & 27 & 29 & 31 & 33 & 35 & 37 & 39 & 41 & 43 & 45 & 47 & 49 & 51 & 53 & 55 & 57 & 59 & 61 & 63 & \mathrm{n} & \text { mean } & \text { SD } \\ 22 & 24 & 26 & 28 & 30 & 32 & 34 & 36 & 38 & 40 & 42 & 44 & 46 & 48 & 50 & 52 & 54 & 56 & 58 & 60 & 62 & 64 & & & \end{array}$

\begin{tabular}{|c|c|c|c|c|c|c|c|c|c|c|c|c|c|c|c|c|c|c|c|c|c|c|c|c|c|c|}
\hline species & 22 & 24 & 26 & 28 & 30 & 32 & 34 & 36 & 38 & 4 & & & & 46 & 48 & 50 & 52 & 54 & 56 & 58 & 60 & 62 & 64 & & & \\
\hline alleni & 1 & 4 & 14 & 10 & 8 & 1 & & & & & & & & & & & & & & & & & & 38 & 26.7 & 2.1 \\
\hline seminud & & & & 1 & 18 & 22 & 8 & 1 & & & & & & & & & & & & & & & & 50 & 31.2 & 1.2 \\
\hline stigmost & & & & & & & & & 1 & 4 & 1 & & 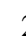 & 2 & & & & & & & & & & 8 & 40.8 & 2.8 \\
\hline elizabetl & $n s i s^{*}$ & & & & & & & & & & & & & & 4 & 2 & 1 & & & & & & & 7 & 48.6 & 1.3 \\
\hline verecunc & & & & & & & & & & & & 2 & & - & 2 & 4 & 3 & 1 & & & & & & 12 & 49.4 & 3.1 \\
\hline reticeps & & & & & & & & & & & & & & & & & & & 1 & 6 & 2 & - & 1 & 10 & 58.5 & 2.3 \\
\hline
\end{tabular}




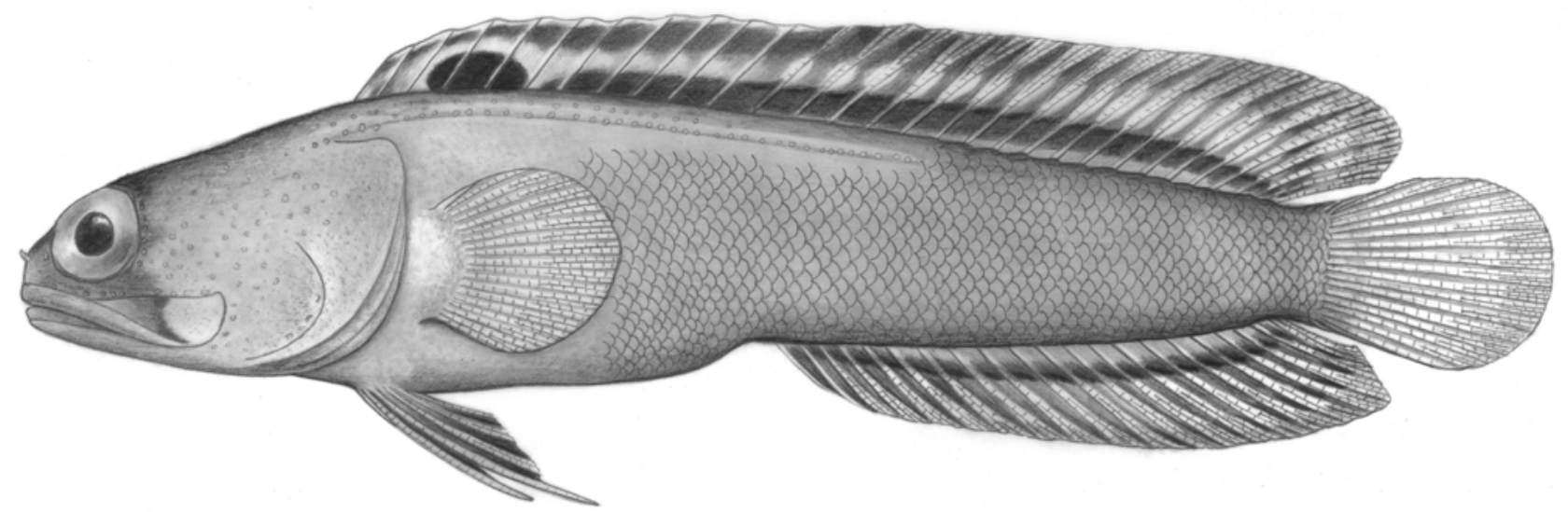

Fig. 8. Opistognathus elizabethensis, holotype, AMS I.27891-010, male, $60.4 \mathrm{~mm}$ SL, Elizabeth Reef. Drawn by Tracy D. Pedersen.

element position 15-18). Lateral line pores moderate, arranged in single series above and below embedded lateralline tubes. Cephalic sensory pores numerous, completely covering most of head, including all of predorsal area except a small area immediately adjacent to dorsal-fin origin; mandibular pore positions 1-3 occupied by relatively large, single pores, 4 th position occupied by $1-3$ pores, 5 th position with 7-11 pores.

Anterior nostril about midway between posterior nostril and dorsal margin of upper lip, consisting of a raised tube with a short tentacle on posterior rim that when depressed does not reach or barely reaches margin of posterior nostril; height of tentacle about 0.5 to 1.0 times maximum diameter of posterior nostril. Dorsal fin moderately low anteriorly, gradually increasing in height posteriorly; profile relatively uniform with only a slight change in fin height at junction of spinous and segmented rays. Dorsal-fin spines moderately short and straight, not curved distally and without flexible tips; skin covering tips of spines with slightly swollen fleshy tabs; all segmented dorsal- and analfin rays branched distally. Outermost segmented pelvic-fin ray not tightly bound to adjacent ray, interradial membrane incised distally. Upper margin of opercle straight and slightly rounded posterodorsally; posterior margin of preopercle indistinct without a free margin. No papillae on inner surface of lips. Fifth cranial nerve passes under A1 $\beta$ section of adductor mandibulae.

Upper jaw not sexually dimorphic, extending 0.6 to 0.9 eye diameters behind posterior margin of orbit; maxilla widest at end and truncate, without flexible lamina posteriorly; supramaxilla small and terminally positioned.
Jaws subequal, lower slightly included. Premaxilla with moderate conical teeth in outer row that become progressively smaller and more closely spaced posteriorly; 1 or 2 rows of much smaller inner teeth anteriorly, and 2 or 3 inner teeth on each side of premaxillary symphysis that are as large or larger than outer teeth and hooked backwards. Dentary with outer row of conical teeth (slightly smaller than outer, anterior premaxillary teeth) that are largest midlaterally; 2 inner rows of teeth (about same size as anterior outer row teeth) anteriorly, with most teeth in innermost row slightly canted backwards. Vomerine teeth 2 or 3 . Infraorbital bones tubular, with wide openings for sensory canals (Fig. 3D); 3rd infraorbital relatively robust and "L" shaped with a slight suborbital shelf.

Measurements of the $60.4 \mathrm{~mm}$ holotype (in parentheses) and 3 paratypes, $66.6-71.4 \mathrm{~mm}$, as percentage of SL: predorsal length (29.5) 28.8-30.9; preanal length (58.6) 55.6-60.6; dorsal-fin base (68.5) 70.6-71.1; anal-fin base (37.7) 32.6-34.7; pelvic fin-length (20.0) 21.5-22.4; caudalfin length (19.7) 19.4-19.6; depth at anal-fin origin (15.6) 16.3-16.8; head length (31.6) 31.2-32.9; orbit diameter (8.5) 8.5-9.5; upper jaw length (18.4) 17.2-18.0. As percentage of head length: postorbital head length (64.7) 63.0-66.4; upper jaw length (58.1) 52.3-57.6; postorbital jaw length (20.2) 16.2-25.3; orbit diameter (27.0) 27.3-28.8.

Preserved coloration. Head and body uniformly tan; inner lining of maxilla and adjacent membranes dark brown, and a dark diagonal blotch externally on upper jaw positioned at rictus of mouth; dorsal fin with an oblong black spot between spines 3-6, encircled by narrow white border and

Table 4. Frequency distributions of lateral-line terminus in relation to total dorsal-fin element position in selected Australian species of Opistognathus (holotype values in boldface). When terminus ended mid-way between two elements, the higher number was used.

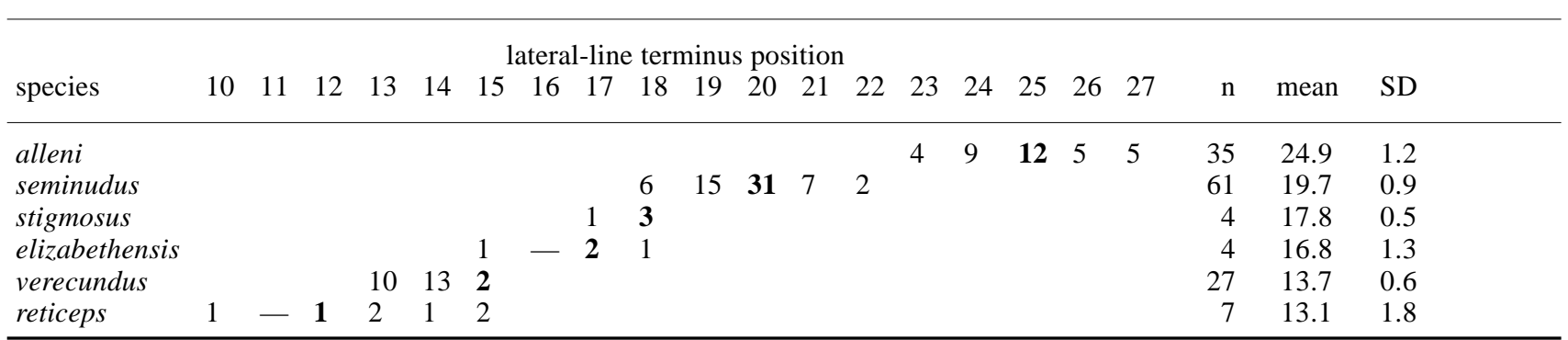




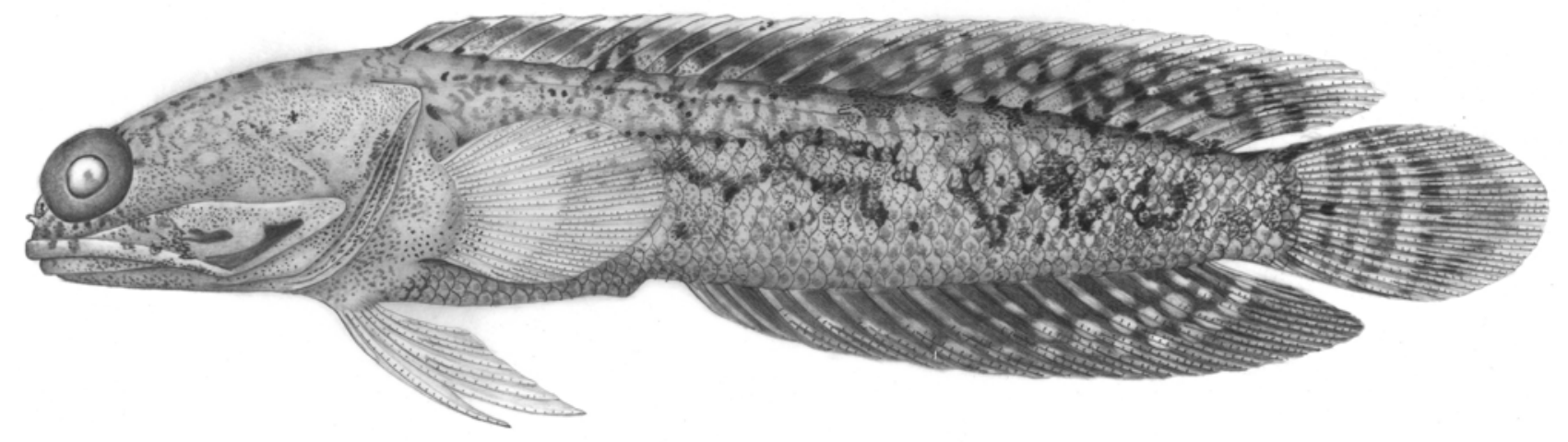

Fig. 9. Opistognathus verecundus, holotype, NTM S.10016-003, male, 52.6 mm SL, Cobourg Peninsula, Northern Territory, Australia. Drawn by Jack R. Schroeder.

extending slightly onto dorsum; remainder of fin with a very narrow pale basal stripe extending length of fin and bordered, in succession, by a narrow dark stripe, another pale stripe (in the largest paratype consisting of a row of narrowly connected white spots, each of which is centred on a fin ray), bordered above by dark pigment; tips of dorsalfin spines with swollen fleshy pads that are mostly dark (these structures pale or white in $O$. alleni and $O$. seminudus); anal fin with a narrow pale basal stripe bordered by a narrower dark stripe, remainder of fin mostly uniform brown; pectoral fins immaculate; caudal fin pale dusky, and pelvic fins dark brownish, darkest on interradial membranes. In the largest paratype the pelvic and anal fins are almost uniformly black, and the belly noticeably dark. This specimens also differs from the others in having a small pair of widely separated, pale, basicaudal spots; these spots perhaps more noticeable owing to the darker caudal fin of this specimen.

Live coloration (A.C. Gill, pers. comm.): body yellowishbrown and pale markings in dorsal fin blue.

Etymology. The specific epithet refers to the type locality. If not an Elizabeth Reef endemic, this species likely occurs only at Elizabeth and the adjacent Middleton Reef (see below).

Distribution. Known only from Elizabeth Reef, where collected between $0-18 \mathrm{~m}$, but possibly also present at the adjacent Middleton Reef $\left(29^{\circ} 30^{\prime} S 159^{\circ} 12^{\prime} \mathrm{E}\right)$. These two coral capped, volcanic seamounts, located about $500 \mathrm{~km}$ off Coffs Harbour, NSW, Australia, represent the southernmost coral atolls in the world (Slater \& Phipps, 1977). Francis (1993) noted that the relatively young Lord Howe Island (6.9-6.4 million years B.P.) and Elizabeth and Middleton Reefs share a large number of species and probably should be treated as a single biogeographic unit. Lord Howe Island $\left(31^{\circ} 33^{\prime} \mathrm{S} 159^{\circ} 4^{\prime} \mathrm{E}\right)$, Elizabeth and Middleton Reefs are only three of more than 20 known volcanic peaks in the Tasman Sea (Slater \& Goodwin, 1973) that form parallel north-south chains along the western margin of the Lord Howe Rise and the trough between Lord Howe Rise and Australia. Although these three peaks are the only ones presently at or above sea level, their faunas may have been derived from older, now submerged, structures.

\section{Opistognathus verecundus n.sp.}

Figs. 2C, 3E, 9, 10; Tables 1-4

Opistognathus sp.—Larson \& Williams, 1997: 366 (listed; Darwin Harbour).

Type material. HolOTYPE: NTM S.10016-003, male (52.6), Australia, Northern Territory, Cobourg Peninsula, E. side Coral Bay, $11^{\circ} 11^{\prime} \mathrm{S} 132^{\circ} 04^{\prime} \mathrm{E}, 5-6 \mathrm{~m}$, Helen K. Larson and P. Homes, 18 Oct. 1981. PARATYPES: 28 specimens, $14.2-48.1 \mathrm{~mm}$, all taken with the holotype. AMS I.33644-001 (4, 35.2-39.4), ANSP 167416 (4, 29.5-48.1, 1 C\&S), NTM S.10016-046 (12, 14.2-47.2), USNM 320261 $(4,25.1-44.8)$, WAM P.30593-001 (4, 33.5-37.3).

Diagnosis. A species of Opistognathus with dorsal fin XXI, 14 or 15 (typically XI, 14); upper jaw sexually dimorphic with flexible lamina posteriorly, end of maxilla slightly rounded (females) becoming increasingly elongate and scimitar-shaped (adult males); oblique scale rows 39-54 in longitudinal series; total gill-rakers on first arch 23-26; spinous dorsal fin with a single brownish spot, if present, between spines $2-4$.

Description. Dorsal-fin rays X-XI, 14 or 15 (typically XI, 14). Anal-fin rays III, 14 (rarely 13 or 15 ). Pectoral-fin rays 18 or 19 . Caudal fin: procurrent rays $4-5+3-5$, segmented rays $8+8$, middle $12-14$ branched, total elements $23-26$; hypural 5 absent. Vertebrae: $10+18$ (19 in one of 29 specimens); last pleural rib on vertebra 10; epineural ribs 11-12. Supraneurals 1 (based on radiographs but in the only $\mathrm{C} \& \mathrm{~S}$ specimen a tiny cartilaginous ball is present in the first interneural space), insertion pattern $0 / \mathrm{S} / 1 / 1+1 / 1 /$. Gill rakers $8-9+15-17=23-26$.

Scales absent on head, nape, above lateral line, pectoralfin base, breast and anterior $1 / 4$ to $1 / 2$ of belly. Body with about 44-54 oblique scale rows in longitudinal series. Lateral-line terminus below verticals from 2 nd to 4 th segmented dorsal-fin rays (total element position 13-15). Lateral line pores numerous, arranged in multiple series above and below embedded lateral-line tubes. Cephalic sensory pores numerous, completely covering most of head, including all of predorsal area except a small area immediately adjacent to dorsal-fin origin; mandibular pore positions 1-3 occupied by relatively large, single pores, 4 th position with 1-3 (usually 2 ) pores, 5th with 3-7 pores. 


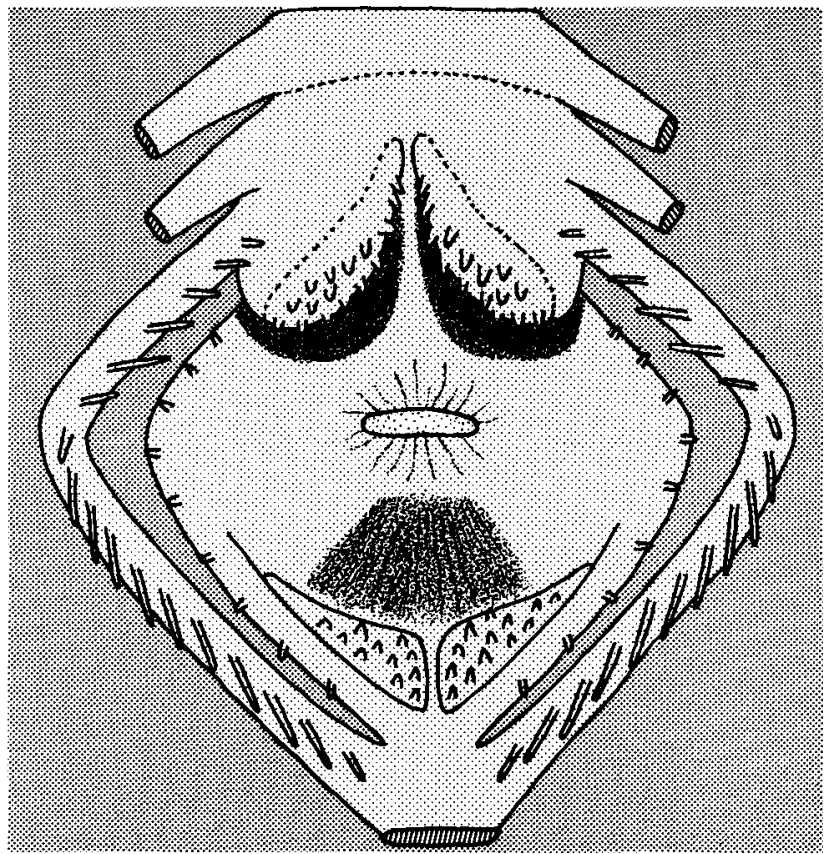

Fig. 10. Semidiagrammatic drawing showing buccal pigmentation in Opistognathus verecundus.

Anterior nostril about mid-way between posterior nostril and dorsal margin of upper lip, consisting of a short tube with posterior rim longer, that when depressed does not reach or just reaches margin of posterior nostril; height of tube shorter than to about equal maximum diameter of posterior nostril. Dorsal fin moderately low anteriorly, with profile relatively uniform without change in fin height at junction of last spine and anterior segmented rays. Dorsalfin spines relatively slender and slightly curved distally, with flexible tips; all segmented dorsal- and anal-fin rays branched distally or 1st anal ray unbranched. Outermost segmented pelvic-fin ray not tightly bound to adjacent ray, interradial membrane incised distally. Upper margin of opercle straight and slightly rounded posterodorsally; posterior margin of preopercle indistinct without a free margin. No papillae on inner surface of lips. Fifth cranial nerve passes under $A 1 \beta$ section of adductor mandibulae.

Upper jaw sexually dimorphic (longest in adult males) and extending 1.1 to 2.1 eye diameters behind posterior margin of orbit; maxilla widest before end, with flexible lamina posteriorly (Fig. 2C), scimitar-shaped in adult males; supramaxilla moderately large and subterminally positioned. Jaws subequal, lower slightly included. Premaxilla with an outer row of moderately large, sharply pointed, conical teeth, those near posterior end of jaw noticeably smaller and more closely spaced; 2 or 3 irregular inner rows of much smaller conical teeth present anteriorly, with those adjacent to premaxillary symphysis slightly enlarged. Dentary with an outer row of conical teeth that are blunter anteriorly, those on posterior half of dentary largest and slightly hooked inward; 2 or 3 inner rows of slightly smaller, conical teeth anteriorly, those in innermost row canted backwards. Vomerine teeth absent. Infraorbital bones tubular, with wide openings for sensory canals (Fig. 3E); 3rd infraorbital relatively robust but without a suborbital shelf. Second pharyngobranchial rod-shaped with distal end slightly expanded.
Measurements of the $52.6 \mathrm{~mm}$ male holotype (in parentheses) and 15 paratypes, 9 o $\delta 35.9-48.1 \mathrm{~mm}$ and 6 ㅇ 9 35.2-47.2 mm, as percentage of SL: predorsal length (31.6) 28.9-32.0; preanal length (55.1) 52.4-56.6; dorsalfin base (74.3) 65.0-76.1; anal-fin base (38.8) 36.3-40.8; pelvic-fin length (20.0) 20.4-22.8; caudal-fin length (21.5) 19.8-22.8; depth at anal-fin origin (15.0) 12.5-16.2; head length (32.7) 29.8-32.6; orbit diameter (8.3) 8.1-9.3; upper jaw length (25.9) 20.4-24.5 $\widehat{\delta} \widehat{0}, 19.0-21.1$ 우 ㅇ. As percentage of head length: postorbital head length (68.9) 65.2-68.4; upper jaw length (79.1) 65.2-78.9 ô ô, 61.666.5 우; postorbital jaw length (52.3) 33.9-45.3 ôे ô, 29.9-35.6 + ; ; orbit diameter (25.3) 25.7-29.9.

Preserved coloration. Head and body ground colour light tan, with darker freckling; in larger specimens branchiostegal membranes and pectoral-fin base finely peppered with melanophores; inner lining of maxilla and adjacent membranes with 2 brownish stripes (best developed in adult males) that when mouth is closed are partially visible as lateral streaks on expanded part of the upper jaw; buccal pigmentation (Fig. 10) consisting of diffuse dusky area on floor of mouth in front of esophageal opening and a pair of slightly separated dark blotches on roof of mouth behind upper pharyngeal toothplates; in some specimens, a series of small dark blotches present on sides and about 8 equally spaced blotches on dorsum along dorsal-fin base; in a few specimens first 2 blotches relatively dark and extending onto dorsal fin; dorsal and anal fins dusky with blotches and pale spots that that tend to form rows; in some specimens a pair of pale basicaudal spots evident and caudal fin with several indistinct narrow dusky bands; pelvic and pectoral fins immaculate.

Etymology. The specific epithet is from the Latin verecundus (bashful or shy), in allusion to the burrowdwelling habit.

Distribution. Known only from the type locality off Cobourg Peninsula, northern Australia, where collected in $5-6 \mathrm{~m}$.

Remarks. This species is apparently most closely related to the allopatric $O$. solorensis Bleeker 1853, known from Indonesia, Philippines and Taiwan. Both have essentially identical upper jaw structures, dentition, fin ray and vertebral counts and buccal pigmentation. Opistognathus verecundus differs from $O$. solorensis in having fewer gill-rakers, with 15-17 (versus 18-20) on the lower limb and a total of 2326 (vs. 27-33), only 44-54 oblique scale rows in longitudinal series (vs. typically 58-69), and only brown spots or markings anteriorly on the spinous dorsal fin, (vs. one or two black spots in this position). 


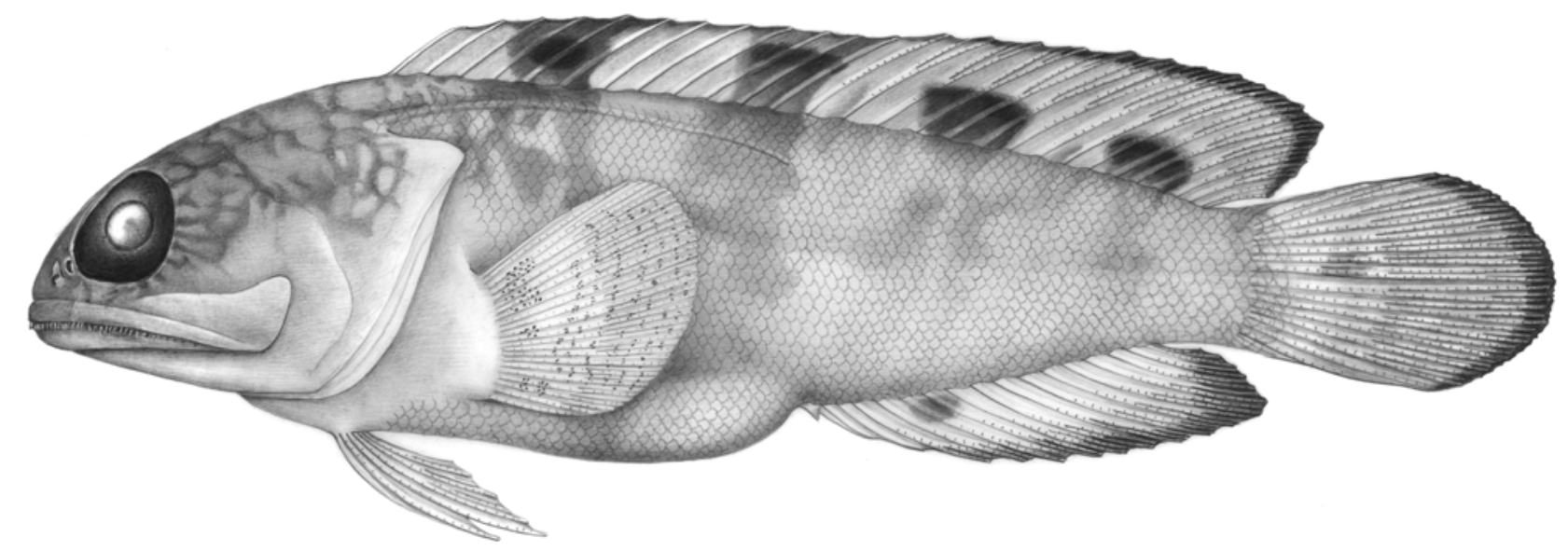

Fig. 11. Opistognathus reticeps, paratype, WAM P.24227, female, 113 mm SL, Napier Broome Bay, Western Australia. Drawn by Jack R. Schroeder.

\section{Opistognathus reticeps n.sp.}

Figs. 2D, 3F, 11; Tables 1-4

Type material. HoLOTYPE: NTM S.10553-004, gravid female (99.4), Australia, Northern Territory, Darwin Harbour, east arm, $12^{\circ} 29^{\prime} \mathrm{S} 130^{\circ} 53^{\prime} \mathrm{E}, 0-1 \mathrm{~m}$, sta. HL $82-$ 49, H. Larson and R. Williams, 6 Sep. 1982. PARATYPES: 7 specimens, 19.4-117.3 mm. WAM P.24227 (113), Napier Broome Bay, Jul. 1973; NTM S.10158-003 (87.2), Van Diemen Gulf, Northern Territory Fisheries, 17 Jan. 1978, Sta. 11/9; AMS IA.7606, gravid female (117.3), Darwin, near jetty, from burrows on mud flat, M. Ward, 31 Jul. 1938; NTM S.10718-032 (63.7, C\&S), Darwin Harbour, east arm, 1.5 m, H. Larson et al., 31 Dec. 1982, Sta. HL 82-91; NTM S.11242-002 (75.4), Darwin Harbour, Wood Inlet, 2 m, H. Larson and R. Williams, 16 Mar. 1984, Sta. HL 84-12; NTM S.10608-013 (19.4), N. Oxley Island, $11^{\circ} 00^{\prime} \mathrm{S} 132^{\circ} 49^{\prime} \mathrm{E}$, 11-12 m, H. Larson et al., 21 Oct. 1982, Sta. HL 82-79; NTM S.13282-001 (84.2), Beagle Gulf, N. of Charles Point, $12^{\circ} 15.4^{\prime} \mathrm{S} 130^{\circ} 37.8^{\prime} \mathrm{E}$, trawled in $23-29 \mathrm{~m}$, R. Williams, 2 Sep. 1992, Sta. RW 92-2.

Diagnosis. A species of Opistognathus with dorsal fin XII, 15 or 16; dorsal fin with 4 dark blotches, the first 2 extending onto distal half of fin; dorsum of head reticulated; lateralline terminus below verticals from 10th spine to $3 \mathrm{rd}$ segmented dorsal-fin ray.

Description. Dorsal-fin rays XII, 15 or 16. Anal-fin rays II, 13 or 14. Pectoral-fin rays 22 or 23 . Caudal fin: procurrent rays $3-4+3-4$, segmented rays $8+8$, middle 12 branched, total elements 22-24; hypural 5 present. Vertebrae: $12+19$; last pleural rib on vertebra 12; epineural ribs 15 . Supraneurals absent, insertion pattern $0 / 0 / 1 / 1+1 / 1 /$. Gill rakers $9-10+17-19=26-29$.

Scales absent on head, nape, pectoral-fin base (largest specimen with a few embedded scales) and breast; 3 or 4 rows of scales present above lateral line anteriorly and 1 or 2 rows posteriorly. Body with about 56-64 oblique scale rows in longitudinal series. Lateral-line terminus below verticals from 10th spine to 3rd segmented dorsal-fin ray (total element position 10-14). Lateral-line pores relatively sparse, mostly arranged in a single series along embedded lateral-line tubes. Cephalic sensory pores relatively numerous, except pores absent on most of nape; 1 st mandibular pore position bipored, all other mandibulopreopercular pore positions occupied by multiple pores too small and numerous to count accurately; infra- and supraorbital pores also very numerous.

Anterior nostril positioned closer to posterior nostril than to margin of upper lip, and consisting of a short tube with a broad tentacle on posterior rim that when depressed extends to or nearly to posterior margin of posterior nostril; height of tentacle about 1.0-1.5 times maximum diameter of posterior nostril. Dorsal fin moderately low anteriorly, increasing in height posteriorly, with profile relatively uniform without change in height at junction of last spine and anterior segmented rays. Dorsal-fin spines relatively slender and only slightly curved, with flexible tips; skin covering tips of dorsal-fin spines somewhat rugose but without fleshy tabs; all segmented dorsal- and anal-fin rays branched distally, except first 1 or 2 anal rays usually unbranched. Outermost segmented pelvic-fin ray not tightly bound to adjacent ray, interradial membrane incised distally. Upper margin of opercle straight and slightly rounded posterodorsally; posterior margin of preopercle distinct, with a free margin. No papillae on inner surface of lips. Fifth cranial nerve passes over A1 $\beta$ section of adductor mandibulae.

Upper jaw not sexually dimorphic, extending about $0.7-$ 1.0 eye diameters behind posterior margin of orbit; maxilla widest at end and rounded, without flexible lamina posteriorly (Fig. 2D); supramaxilla present, relatively small and terminally positioned. Jaws subequal, lower slightly included. Both jaws with an outer row of enlarged conical teeth that are relatively straight and slant forward, especially anteriorly; 1 or 2 irregular rows of much smaller inner teeth present anteriorly, those adjacent to premaxillary symphysis slightly enlarged and canted posteriorly. Vomerine teeth absent. Infraorbital bones relatively slender and tubular (Fig. 3F); 3rd infraorbital with a slight suborbital shelf. Second pharyngobranchial rod-shaped with distal end slightly expanded.

Measurements of the $99.4 \mathrm{~mm}$ holotype (in parentheses) and 5 paratypes, $75-117 \mathrm{~mm}$, as percentage of SL: predorsal length (39.0) 34.6-40.0; preanal length (63.9) 56.9-67.0; dorsal-fin base (62.6) 60.1-69.1; anal-fin base (26.6) 25.430.1; pelvic-fin length (22.6) 20.4-25.3; caudal-fin length 
(25.8) 24.1-29.8; depth at anal-fin origin (24.1) 22.9-25.5; head length (39.2) 37.1-41.2; orbit diameter (12.5) 12.513.9; upper jaw length (25.7) 24.7-26.3. As percentage of head length: postorbital head length (61.8) 57.9-61.6; upper jaw length (65.4) 62.2-67.4; postorbital jaw length (30.1) 23.0-29.8; orbit diameter (31.8) 32.1-35.1.

Preserved coloration. Dorsum of head, snout, upper part of opercle, and nape reticulated with irregular pale markings or spots, remainder of head and body mostly pale to light dusky, except blotches in dorsal fin usually continue across the body as faint bands (best developed in smaller specimens), and a similar basicaudal band may be present on caudal peduncle; dorsal fin with four dark blotches that extend slightly onto dorsum; interradial membranes immediately adjacent to blotches lighter than rest of fin and almost clear in the smaller paratypes; anterior two blotches extending to or almost to distal margin of fin, others becoming progressively smaller in height; 1 st blotch positioned between spines 3-6, 2nd between spines 9-12, 3 rd between rays 3-6 and 4th between rays 10-14; dorsal and anal fins with narrow dark margins, widest posteriorly; remainder of anal fin pale or with one or two dark spots, slightly smaller than pupil diameter, in basal half of fin aligned with blotches in dorsal fin; caudal fin pale except for narrow dark margin; pelvic fins immaculate and pectoral fins faintly speckled.

Etymology. The specific epithet is from the Latin rete (net) and ceps (head), in reference to the reticulated dorsum of the head that is a distinguishing feature of this species. The name should be treated as a noun in apposition.

Distribution. Known only from northern Australia.

Remarks. Only Opistognathus reticeps and four other species of jawfishes have 12 dorsal-fin spines, and all have different colour patterns (see following identification key). Opistognathus reticeps apparently is much smaller (largest individual, a $117 \mathrm{~mm}$ SL gravid female) than the other four, all of which attain at least $200 \mathrm{~mm}$. The largest specimens examined $(\mathrm{mm}$ SL) of the others are: O. inornatus (409); O. papuensis (339); O. reticulatus (368); O. latitabundus (216).

\section{Status of Tandya Whitley}

Whitley (1930) established the genus Tandya (type by original designation, Opistognathus maculatus Alleyne \& Macleay, $1877=$ O. papuensis Bleeker, 1868) for Australian jawfishes that have 12 dorsal-fin spines and upper jaws with a truncate maxilla extending posterior to a vertical from the posterior margin of the orbit. He contrasted his new genus only with Gnathypops Gill (type species Opistognathus maxillosus Poey, 1860), which was erroneously reported to have 8 (actually 11) dorsal-fin spines. SmithVaniz (1997) redescribed $O$. maxillosus, recognizing Gnathypops as a junior synonym of Opistognathus Cuvier. Inexplicably, both Whitley (1930) and McKay (1969) assigned Opistognathus darwiniensis Macleay, 1878 to Tandya although it has only 11 dorsal-fin spines. Three other jawfishes with 12 dorsal-fin spines that have sometimes been referred to Tandya are Opistognathus inornatus Ramsay \& Ogilby, 1887, Tandya latitabunda Whitley, 1937 and Tandya reticulata McKay, 1969. Opistognathus inornatus differs from the allopatric $O$. papuensis only in colour pattern and its taxonomic rank is subjective.

Species in the following key that have 12 (rarely 13) dorsal-fin spines also have more precaudal vertebra than other opistognathids (12 or 13 versus 10 or 11), except $O$. darwiniensis with typically $12+19$ vertebrae and 10 or 11 (usually 11) dorsal-fin spines. Opistognathus darwiniensis is also exceptional in having a second, irregularly developed, tubed lateral line (often with one or more branches on belly) present along the lower sides near the anal-fin origin. Numbers of dorsal-fin spines and precaudal vertebrae vary widely among percoids, and in the absence of a reasonably supported sister-group hypothesis for the Opistognathidae (see discussion in Gill \& Mooi, 1993), polarity of such meristic characters is equivocal. High numbers of spines and precaudal vertebrae could have evolved in the ancestor of the Opistognathidae; that possibility combined with the lack of character state concordance in $O$. darwiniensis, leads me to retain these species in a "catch-basket" Opistognathus, the oldest available generic name in the family, pending independent corroborative evidence of monophyly.

\section{Key to Australian jawfishes}

1 First 5-9 dorsal-fin spines transversely forked distally (posteriorly spines successively less deeply and more narrowly forked); skin covering spinous dorsal fin forming a broad dorsal hood to accommodate transversely forked spines; segmented anal-fin rays 10 or 11

_ Anterior dorsal-fin spines not transversely forked; skin covering spinous dorsal fin not forming a broad dorsal hood; segmented anal-fin rays $10-19$

2 Posterior edge of opercle and adjacent branchiostegal membranes dark and conspicuous; dorsal, anal, and caudal fins with two, broad dark stripes or bands (Japan, Indonesia, Great Barrier Reef, and New Caledonia) Stalix histrio Jordan \& Snyder, 1902

Posterior edge of opercle and adjacent branchiostegal membranes not conspicuously pigmented; dorsal, anal and caudal fins without dark stripes or bands (western Australia) 


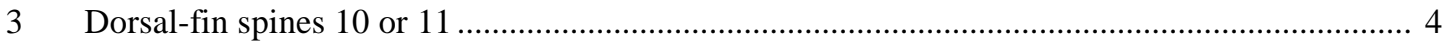

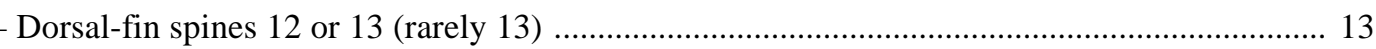

4 Body with 2 separate lateral lines, the ventral one irregularly developed along lower side in region of anal-fin origin, often with one or more branches on belly; head covered with close-set, tiny, brown spots and pelvic fins usually strongly barred; precaudal vertebrae 12 or 13 (northwestern Australia). Opistognathus darwiniensis Macleay, 1878

— Body with a single, dorsally positioned lateral line; colour pattern not as above; precaudal vertebrae 10 or 11

5 Segmented dorsal- and anal-fin rays 11-13 and 10-12, respectively 6

Segmented dorsal- and anal-fin rays 14-20 and 13-19, respectively 8

6 Opercle with a conspicuous dark blotch; scales on belly minute and distinctly embedded; body with about 80-99 oblique scales in longitudinal series; vomerine teeth 1-3; upper gill-rakers 1417 (eastern Australia) Opistognathus eximus (Ogilby, 1908)

_ Opercle without a dark blotch; scales on belly, if present, small to moderate and not distinctly embedded; body with about 41-62 oblique scales in longitudinal series; vomerine teeth absent; upper gill-rakers 9-12

$7 \quad$ Spinous dorsal without an ocellus; soft dorsal and anal fins mostly dark with a narrow pale basal stripe; no dark chin bar; outer premaxillary teeth relatively straight and with distinctly blunt tips; nape at least partially scaled (gulfs of Thailand and Carpentaria) Opistognathus macrolepis Peters, 1866

- Spinous dorsal fin with a prominent ocellus; coloration of soft dorsal and anal fins not as above; dark chin bar present; outer premaxillary teeth variously curved and with pointed tips; nape usually naked (western Pacific, including Great Barrier Reef, Fiji and Samoa islands). Opistognathus sp. "chinstrap jawfish"

8 Floor of mouth between dentaries and "tongue" dark brown; dorsal fin X, 16-18, rarely 16; body with about 80-99 oblique scale rows in longitudinal series (eastern Australia) Opistognathus jacksoniensis Macleay, 1881

- Floor of mouth between dentaries and "tongue" pale; number of dorsal-fin spines and rays not in above combination; body with about 21-54 oblique scales in longitudinal series 9

9 Posterior end of upper jaw produced as a thin flexible lamina in adults (beginning as a slight posteroventral projection in small juveniles); in at least adult males upper jaw extends to or beyond posterior margin of preopercle and appears somewhat scimitarshaped; roof of mouth behind upper pharyngeal toothplates with a pair of slightly separated dark blotches; total dorsal-fin elements 25 (rarely 26); lateral-line terminus below verticals from 2 nd to 4 th segmented dorsal-fin rays (northern Australia)

Opistognathus verecundus n.sp.

Posterior end of upper jaw rigid in adults, without a flexible lamina; upper jaw not extending to posterior margin of preopercle, truncate or moderately rounded but never scimitar-shaped; roof of mouth behind upper pharyngeal toothplates immaculate; total dorsal-fin elements 25-30; lateral-line terminus below verticals from 4th to 17 th segmented dorsal-fin rays

10 Segmented dorsal- and anal-fin rays $14-16$ and 14 or 15 , respectively; body naked anterior to a vertical between ultimate spine and 2nd segmented dorsal-fin rays; caudal vertebrae 18 (Great Barrier Reef)

Opistognathus seminudus n.sp. 
- Segmented dorsal- and anal-fin rays 18-20 and 17-19, respectively; body naked anterior to a vertical between 5 th and 7th spines or 6th and 9th segmented dorsal-fin rays; caudal vertebrae 22 or 23

11 Body naked anterior to a vertical line from 6th to 9th segmented dorsal-fin rays; lateral line terminus below verticals between 13th and 17th segmented dorsal-fin rays; body with 21-31 oblique scale rows (western Australia)

Body naked anterior to a vertical from 5th to 7 th dorsal-fin spines; lateral line terminus below verticals between 4 th and 8 th segmented dorsal-fin rays; body with $38-51$ oblique scale rows

12 Spinous dorsal fin with an oblong black spot (encircled by narrow white border) between spines 3-6 that extends slightly onto dorsum; dorsal-fin spines 11; vomerine teeth 2 or 3 ; sides of body uniformly pigmented (Elizabeth Reef) Opistognathus elizabethensis n.sp.

_ Spinous dorsal fin pigmentation not as above; dorsal-fin spines 10; vomerine teeth absent; sides of body with longitudinal row of 7 or 8 large pale spots and a few conspicuous small, black spots (Great Barrier Reef and Coral Sea Plateau)

13 Dorsal fin with 4 or 5 large dark blotches that extend onto dorsum; lateral line terminus below verticals between 10th spine and 5th segmented dorsal-fin ray; 56-80 oblique scale rows in longitudinal series

Dorsal fin pigmentation not as above; lateral line terminus below verticals between 6th and 13th segmented dorsal-fin ray; 78-129 oblique scale rows in longitudinal series

14 Dorsal fin with 4 dark blotches, first blotch extending onto distal half of fin; inner surface of mouth, and skin connecting dentary and maxilla pale; dorsum of head reticulated; total gill-rakers on first arch 26-29; vertebrae 12+19 (northern Australia).

— Dorsal fin with 5 dark blotches, first blotch only on base of fin; much of inner surface of mouth, and skin connecting dentary and maxilla (hidden from view when mouth is closed) darkly pigmented; dorsum of head uniformly pigmented; total gill-rakers on first arch 23 or 24; vertebrae 13+19-21 (northern Australia and southern Papua New Guinea) Opistognathus latitabundus (Whitley, 1937)

15 Body with pale reticulate network enclosing irregular tan blotches, each of which has one to several small, dark-brown spots; pectoralfin base (laterally and mesially) with a conspicuous dark spot about half diameter of eye; pelvic and anal fins white; vertebrae $13+18$ (northwestern Australia).... Opistognathus reticulatus (McKay, 1969)

_ Body with no to many dark spots on an otherwise uniformly pigmented body; pectoral-fin base not pigmented as above, either unmarked or typically with tiny black spots; pelvic and anal fins usually brownish, the anal fin with or without small spots; vertebrae $12+18-20$ (usually 19)

16 Body with numerous small spots, especially on dorsum of head; pectoral fin with several to many tiny dark spots; background coloration of body pale (in life, light tan), darker dorsally (Waigeo and Queensland to Darwin, Australia) Opistognathus papuensis Bleeker, 1868

Body usually without spots, if present, spots relatively large and sparse; pectoral fin typically unspotted; background coloration of body dark brown (Western Australia) Opistognathus inornatus Ramsay \& Ogilby, 1887 
ACKNOWLEDGMENTS I thank the following for loans of specimens: G.R. Allen (WAM), W.N. Eschmeyer (CAS), A.C. Gill (BMNH), R.D. Mooi (MPM), J.C. Paxton (AMS), J.E. Randall (BPBM), H.K. Larson (NTM), and V.G. Springer and J.T. Williams (USNM). Colour photographs of jawfishes were generously provided by G.R. Allen, R.D. Mooi, and P.C. Heemstra, South African Institute of Aquatic Biology (formerly RUSI). I also thank R.D. Mooi for discussion of problems involving opistognathid intrafamilial relationships. The manuscript benefited from comments provided by Martin Gomon and an anonymous reviewer.

\section{References}

Ahlstrom, E.H., J.L. Butler \& B.Y. Sumida, 1976. Pelagic stromateoid fishes (Pisces, Perciformes) of the eastern Pacific: kinds, distributions, and early life histories and observations on five of these from the northwest Atlantic. Bulletin of Marine Sciences 26(3): 285-402.

Allen, G.R., \& R. Swainston, 1988. The Marine Fishes of NorthWestern Australia. A Field Guide for Anglers and Divers. Perth: Western Australian Museum, 201 pp.

Alleyne, H.G., \& W. Macleay, 1877. The ichthyology of the Chevert Expedition. Proceedings of the Linnean Society of New South Wales 1(3): 261-281.

Bleeker, P., 1853. Bijdrage tot de Kennis der ichthyologische fauna van Solor. Natuurkundige Tijdschrift voor Nederlandsch-Indië 5: 67-96.

Bleeker, P., 1868. Description de trois espèces inédites de poissons des iles D'Amboine et de Waigiou. Verslagen en Mededeelingen der Koninklijke Akademie van Wetenschappen. 2(2): 331-335.

Francis, M.P., 1993. Checklist of the coastal fishes of Lord Howe, Norfolk, and Kermadec Islands, southwest Pacific Ocean. Pacific Science 47(2): 136-170.

Gill, A.C., \& R.D. Mooi, 1993. Monophyly of the Grammatidae and of the Notograptidae, with evidence for their phylogenetic positions among perciforms. Bulletin of Marine Science 52 (1): 327-350.

Gill, A.C., \& S.E. Reader, 1992. Fishes. In Reef Biology: A Survey of Elizabeth and Middleton Reefs, South Pacific, pp. 90-93, 193-228. Kowari vol. 3. Sydney: Australian Museum.

Jordan, D.S., \& J.O. Snyder, 1902. A review of the trachinoid fishes and their supposed allies found in the waters of Japan. Proceedings of the United States National Museum 24(1263): 461-497.

Larson, H.K., \& R.S. Williams, 1997. Darwin Harbour fishes: a survey and annotated checklist. In Proceedings of the Sixth International Marine Biological Workshop. The Marine Flora and Fauna of Darwin Harbour, Northern Territory, ed. J.R. Hanley, G. Caswell, D. Megirian and H.K. Larson, pp. 339380. Museums and Art Galleries of the Northern Territory and the Australian Marine Sciences Association: Darwin, Australia.
Leviton, A.E., R.H. Gibbs Jr., E. Heal \& C.E. Dawson, 1985. Standards in herpetology and ichthyology. Part I. Standard symbolic codes for institutional resource collections in herpetology and ichthyology. Copeia 1985(3): 802-832.

Macleay, W., 1878. The fishes of Port Darwin. Proceedings of the Linnean Society of New South Wales 2: 344-367.

Macleay, W., 1881. Descriptive catalogue of the fishes of Australia. Part II. Proceedings of the Linnean Society of New South Wales 5(4): 510-629.

McKay, R.J., 1969. The genus Tandya in Western Australia, with a description of a new opistognathid fish, Tandya reticulata sp. nov. Journal of the Royal Society of Western Australia 52(1): 1-2.

Ogilby, J.D., 1908. On new genera and species of fishes. Proceedings of the Royal Society of Queensland 21: 1-26.

Peters, W., 1866. Mittheilung über Fische (Protopterus, Auliscops, Labrax, Labracoglossa, Nematocentris, Serranus, Scorpis, Opisthognathus, Scombresox, Acharnes, Anguilla, Gymnomuraena, Chilorhinus, Ophichthys, Helmichthys). Monatsbericht der Königlich Preussischen Akademie der Wissenschaften zu Berlin (for 1866): 509-526.

Poey, F., 1860. Poissons de Cuba. In Memorias sobre la historia natural de la isla de Cuba, acompanados de sumarios Latinos y extractos en Francés 2: 115-356.

Ramsay, E.P., \& J.D. Ogilby, 1887. Descriptions of new Australian fishes. Proceedings of the Linnean Society of New South Wales. Ser. 2, 2(3): 561-564.

Randall, J.E., G.R. Allen \& R.C. Steene, 1990. Fishes of the Great Barrier Reef and Coral Sea. Honolulu: University of Hawaii Press, 507 pp.

Russell, B.C., 1983. Annotated checklist of the coral reef fishes in the Capricorn-Bunker Group Great Barrier Reef Australia. Great Barrier Reef Marine Park Authority Special Publication Series 1: $184 \mathrm{pp}$.

Slater, R.A., \& R.H. Goodwin, 1973. Tasman Sea guyots. Marine Geology 14(2): 81-99.

Slater, R.A., \& C.V.G. Phipps, 1977. A preliminary report on the coral reefs of Lord Howe Island and Elizabeth Reef, Australia. Proceedings of the 3rd International Coral Reef Symposium 1977: 314-318. Miami.

Smith-Vaniz, W.F., 1989. Revision of the jawfish genus Stalix (Pisces: Opistognathidae), with descriptions of four new species. Proceedings of the Academy of Natural Sciences of Philadelphia 141: 375-407.

Smith-Vaniz, W.F., 1997. Five new species of jawfishes (Opistognathus: Opistognathidae) from the western Atlantic Ocean. Bulletin of Marine Sciences 60(3): 1073-1128.

Whitley, G.P., 1930. Ichthyological miscellanea. Memoirs of the Queensland Museum 10(1): 8-31.

Whitley, G.P., 1937. Studies in Ichthyology No. 10. Records of the Australian Museum 20(1): 3-24, pl. 2.

Manuscript received 6 February 2003, revised 23 April 2003 and accepted 28 May 2003.

Associate Editor: J.M. Leis. 